\title{
The ammonoid fauna of the Prionocyclus germari Zone (upper Turonian, upper Cretaceous) from Rochefort-en-Valdaine (Drôme, France)
}

\author{
Cyril Baudouin ${ }^{1,2}$ \\ Gérard DeLANOY ${ }^{2,3}$ \\ Christina I FRI M ${ }^{4}$ \\ Josep Anton Moreno-Bedmar ${ }^{5}$
}

\begin{abstract}
The late Turonian ammonoid fauna of Rochefort-en-Valdaine (Drôme, France) is herein described in detail and the intraspecific variability of Vocontiiceras vocontiense DIEBOLD et al., 2018, is studied. The ammonoid assemblage ( 9 taxa identified) was deposited within the Prionocyclus germari Zone, which was defined in Germany, and is now also documented in southeastern France. Moreover, the co-occurrence of the heteromorph ammonoids Hyphantoceras (Hyphantoceras) flexuosum (SCHLÜTER) and Hyphantoceras (Hyphantoceras) ernsti WIESE indicates the lower part of the Prionocyclus germari Zone.
\end{abstract}

Key-words:

- Ammonoidea;

- Turonian;

- Drôme (France);

- biostratigraphy;

- intraspecific variability

Citation : Baudouin C., Delanoy G., Ifrim C. \& Moreno-Bedmar J.A. (2018).- The ammonoid fauna of the Prionocyclus germari Zone (upper Turonian, upper Cretaceous) from Rochefort-en-Valdaine (Drôme, France).- Carnets Geol., Madrid, vol. 18, no. 14, p. 313-351.

Résumé : La faune d'ammonites de la Zone à Prionocyclus germari (Turonien supérieur) de Rochefort-en-Valdaine (Drôme, France).- La faune d'ammonites du Turonien supérieur de Rochefort-en-Valdaine (Drôme, France) est décrite en détail et la variabilité intraspécifique de Vocontiiceras vocontiense DiebolD et al., 2018, est étudiée. Cette faune d'ammonites (9 taxons identifiés) est caractéristique de la Zone à Prionocyclus germari, préalablement définie en Allemagne, et dont la présence est maintenant démontrée dans le sud-est de la France. De plus, la présence des ammonites hétéromorphes Hyphantoceras (Hyphantoceras) flexuosum (SCHLÜTER) et Hyphantoceras (Hyphantoceras) ernsti WIESE indique plus précisement la partie inférieure de la Zone à Prionocyclus germari.

\footnotetext{
1 16, rue Frédéric Mistral, 26200 Montélimar (France)

cyril.baudouin@gmail.com

${ }^{2}$ Centre d'Études Méditerranéennes, 04170 St André les Alpes (France)

3 Département des Sciences de la Terre, Université de Nice-Sophia-Antipolis, Faculté des Sciences, 28 avenue Valrose, 06108 Nice cedex 2, (France)

delanoy@unice.fr

${ }^{4}$ Institut für Geowissenschaften, Universität Heidelberg, Im Neuenheimer Feld 234, 69120 Heidelberg (Germany) christina.ifrim@geow.uni-heidelberg.de

${ }^{5}$ Institut für Geowissenschaften, Universität Heidelberg, Im Neuenheimer Feld 234, 69120 Heidelberg (Germany) Instituto de Geología, Universidad Nacional Autónoma de México, Ciudad Universitaria, Coyoacán, 04510 Ciudad de México (Mexico)

josepamb@geologia.unam.mx
}

Published online in final form (pdf) on December 31, 2018

[Editor: Bruno GRANIER; language editor: Simon MITCHELL] 
Mots-clefs :

- Ammonoidea ;

- Turonien ;

- Drôme (France) ;

- biostratigraphie ;

- variation intraspécifique

\section{I . Introduction}

For more than a century, the Turonian of south-eastern France has been the subject of numerous studies that outlined the occurrence of significant ammonoid fauna (RoMAN, 1912; Roman \& MAZERAN, 1913; Faraud, 1934, 1936, 1940, 1951; SORNAY, 1939, 1946, 1950, 1964; MenNessier, 1950; LetOuRneur \& Porthault, 1966; THOMEL, 1969, 1992, 1993; PORTHAULT, 1974; AMÉDRo et al., 1983; DeValque et al., 1983; KeNNEDY, 1994; Jolet et al., 2001; DieBOLD, 2012; RoBASZYNSKI et al., 2014; DieBOLD et al., 2018) and allowed the establishment of a regional biostratigraphic zonal scheme (Fig. 1) that can be used throughout western Europe (KeNNEDY, 1994; RoBASZYNSKI et al., 2014).

As pointed out by RoBASZYNSKI et al. (2014), all Turonian ammonites zones were identified in south-eastern France, with the exception of the latest Turonian Prionocyclus germari Zone of the standard zonation of western Europe. However, this latter ammonite zone was recognised in the unpublished PhD Thesis of DIEBOLD (2012), and more recently in the work of Diebold et al. (2018) by the presence of the index species Prionocyclus germari (Reuss, 1845) at Rochefort-en-Valdaine (Drôme, France).

We describe here the entire ammonoid fauna of the Rochefort-en-Valdaine section (Drôme, France), and complete the description of Vocontiiceras vocontiense DIEBOLD et al., 2018, in order to provide a better understanding of intraspecific variability within this taxon. Additionally, the description and illustration of $\mathrm{Hy}$ phantoceras (Hyphantoceras) ernsti WIESE, 2000, and Hyphantoceras (Hyphantoceras) flexuosum (SCHLÜTER, 1872) confirm the presence of the lower part of the Prionocyclus germari Zone in south-eastern France, by correlation with north-western Germany where the Prionocyclus germari Zone is well developed (Kaplan \& KenNedy, 1996; WieSe, 2000a, 2009 with references).
The following taxa are identified at Rochefort-en-Valdaine: Gaudryceras mite (HAUER, 1866), cf. Mesopuzosia MATsumoto, 1954, Lewesiceras mantelli C.W. WRIGHT \& E.V. WRIGHT, 1951, Prionocyclus germari (Reuss, 1845), Vocontiiceras vocontiense DieBOLD et al., 2018, Hyphantoceras (Hyphantoceras) flexuosum (SCHLÜTER, 1872), Hyphantoceras (Hyphantoceras) ernsti WIESE, 2000, Sciponoceras bohemicum bohemicum (FRITSCH, 1872) and Scaphites geinitzii ORBIGNY, 1850. Thanks to new material, a redescription and a study of intraspecific variation of Vocontiiceras vocontiense DIEBOLD et al., 2018, complements the understanding of the family Collignoniceratidae which is of considerable importance for the biostratigraphic recognition of the Turonian/Coniacian boundary (KENNEDY \& WALASZCZYK, 2004; Diebold, 2012).

\section{II . Previous works and biostratigraphic settings}

The ammonoids studied herein originate from a single section situated near Rocheforten-Valdaine (Fig. 2) and were collected by C. BAUdouin and H. Chatelier from a thick stratigraphic interval (approximately $2 \mathrm{~m}$; upper part of bed c14; DIEBOLD et al., 2018, Fig. 2). This section belongs to the "Calcaires blancs à silex", a lithostratigraphic interval that was originally described by SORNAY (1950, p. 62). It consists of more or less sandy and glauconitic white limestones. The presence of glaucony could indicate a slight amount of condensation, or a low sedimentation rate (AMOROSI, 2012). FALLOT (1885, p. 178), SORnAY (1939, p. 116; 1950 , p. 62), Moullade (in Middemiss \& MoulLADE, 1968, p. 321) and PoRThault (1974, p. 155) reported the occurrence of ammonoids in this section (Table 1) and proposed a late Turonian age for the fauna without identifying ammonite zones. 


\begin{tabular}{|c|c|c|c|c|c|}
\hline \multirow{3}{*}{ 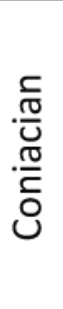 } & & \multirow{2}{*}{$\begin{array}{c}\text { Standard } \\
\text { ammonites } \\
\text { zonation } \\
\text { (Western } \\
\text { Europe) }\end{array}$} & \multirow[b]{2}{*}{ North Germany } & \multicolumn{2}{|c|}{ Anglo-Paris Basin } \\
\hline & & & & Chalks & Tuffeaux \\
\hline & & $\begin{array}{c}\text { Forresteria } \\
\text { petrocoriensis }\end{array}$ & $\begin{array}{c}\text { Forresteria } \\
\text { petrocoriensis }\end{array}$ & & \\
\hline \multirow{10}{*}{ 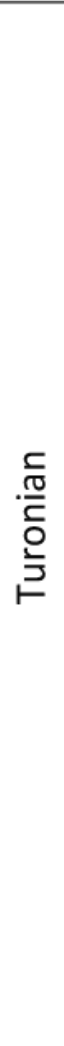 } & \multirow{3}{*}{$\begin{array}{l}\frac{1}{2} \\
\frac{2}{2}\end{array}$} & $\begin{array}{l}\text { Prionocyclus } \\
\text { germari }\end{array}$ & $\begin{array}{l}\text { Prionocyclus } \\
\text { germari }\end{array}$ & & \\
\hline & & $\begin{array}{c}\text { Subprionocyclus } \\
\text { bravaisianus }\end{array}$ & $\begin{array}{c}\text { Subprionocyclus } \\
\text { bravaisianus }\end{array}$ & $\begin{array}{c}\text { Subprionocyclus } \\
\text { neptuni }\end{array}$ & \\
\hline & & $\begin{array}{l}\text { Romaniceras } \\
\text { deverianum }\end{array}$ & & $\begin{array}{c}\text { Romaniceras } \\
\text { deverianum }\end{array}$ & \\
\hline & \multirow{4}{*}{$\frac{\frac{\omega}{0}}{\frac{0}{\varepsilon}}$} & $\begin{array}{l}\text { Romaniceras } \\
\text { mexicanum }\end{array}$ & \multirow{4}{*}{$\begin{array}{c}\text { Collignoniceras } \\
\text { woollgari }\end{array}$} & \multirow{4}{*}{$\begin{array}{c}\text { Collignoniceras } \\
\text { woollgari }\end{array}$} & \\
\hline & & $\begin{array}{l}\text { Romaniceras } \\
\text { ornatissimum }\end{array}$ & & & $\begin{array}{l}\text { Romaniceras } \\
\text { ornatissimum }\end{array}$ \\
\hline & & $\begin{array}{l}\text { Romaniceras } \\
\text { kallesi }\end{array}$ & & & $\begin{array}{l}\text { Romaniceras } \\
\text { kallesi }\end{array}$ \\
\hline & & $\begin{array}{c}\text { Kamerunoceras } \\
\text { turoniense }\end{array}$ & & & $\begin{array}{c}\text { Kamerunoceras } \\
\text { turoniense }\end{array}$ \\
\hline & \multirow{3}{*}{ 㐫 } & $\begin{array}{l}\text { Mammites } \\
\text { nodosoides }\end{array}$ & $\begin{array}{l}\text { Mammites } \\
\text { nodosoides }\end{array}$ & $\begin{array}{l}\text { Mammites } \\
\text { nodosoides }\end{array}$ & $\begin{array}{l}\text { Mammites } \\
\text { nodosoides }\end{array}$ \\
\hline & & $\begin{array}{l}\text { Fagesia } \\
\text { catinus }\end{array}$ & & $\begin{array}{l}\text { Fagesia } \\
\text { catinus }\end{array}$ & \\
\hline & & $\begin{array}{l}\text { Watinoceras } \\
\text { devonense }\end{array}$ & $\begin{array}{l}\text { Watinoceras } \\
\text { Coloradoense }\end{array}$ & $\begin{array}{c}\text { Watinoceras } \\
\text { devonense }\end{array}$ & \\
\hline
\end{tabular}

Figure 1: Biozonation of the Turonian (Late Cretaceous) of northwest Europe used in this work (from ROBASZYNSKI et al., 2014).

The section and its ammonoid fauna (Table 1) were studied with more detail by DIEBOLD (2012) who presented a composite log of the late Turonian of Rochefort-en-Valdaine. The presence of Prionocyclus cf. germari (Reuss, 1845), Hyphantoceras (Hyphantoceras) cf. flexuosum (SCHLÜTER, 1872) and Hyphantoceras (Hyphantoceras) cf. ernsti WIESE, 2000, allowed him to identify the Prionocyclus germari Zone and to correlate the fauna of Rochefort-en-Valdaine with a level that lays between Marl $M_{G}$ and the "Heteromorph Beds" of northern Germany (WIESE, 2000a; WALASZCZYK et al., 2010), i.e., the uppermost part of the Salder and lowermost part of the Erwitte formations (NIEBUHR et al., 2007).

More recently, Diebold et al. (2018) recorded Vocontiiceras vocontiense DIEBOLD et al., 2018, from this section, an endemic species belonging to the Collignoniceratidae C.W. WRIGHT \& E.V. WRIGHT, 1951.

\section{I . Methodology}

Measurements are given in millimetres; on distorted specimens, they are subject to imprecision and are written in italic. In the case of planispiral ammonoids, the classic measurements (Fig. 3 ) of the diameter of the umbilicus $(U)$, height $(W H)$ and width $(W B)$ of the whorls were made at the maximum diameter $(D)$, and only sometimes at an intermediate diameter when the preservation was sufficient to provide useful measurements. In the case of Hyphantoceras HYATT, 1900, only the measurements of height $(W H)$ and of thickness (WB) of the whorls were made, as well as the maximum diameter for specimen no. Rch14. For Sciponoceras HYATT, 1894, only the maximum size ("L") and the maximum height of whorl $(W H)$ were able to be measured. For Scaphites PARKINSON, 1811 , the measurements made are the maximum size $(L)$, the diameter of the spire $(D s)$, as well as the height of whorl $(W H)$ and its width $(W B)$ on the flexus. 
Table 1: List of the ammonoids reported from the Rochefort-en-Valdaine section in previous works.

FALLOT $(1885$, p. 178$)$

SORNAY $(1939$, p. 116)

SORNAY $(1950$, p. 62)

Moullade (in Middlemiss \& MOULLAde, 1968 , p. 321)

PORTHAULT (1974, p. 155)

DiEBOLD (2012, p. 136)

DieBOLD et al. (2018, p. 376 and Fig. 2)

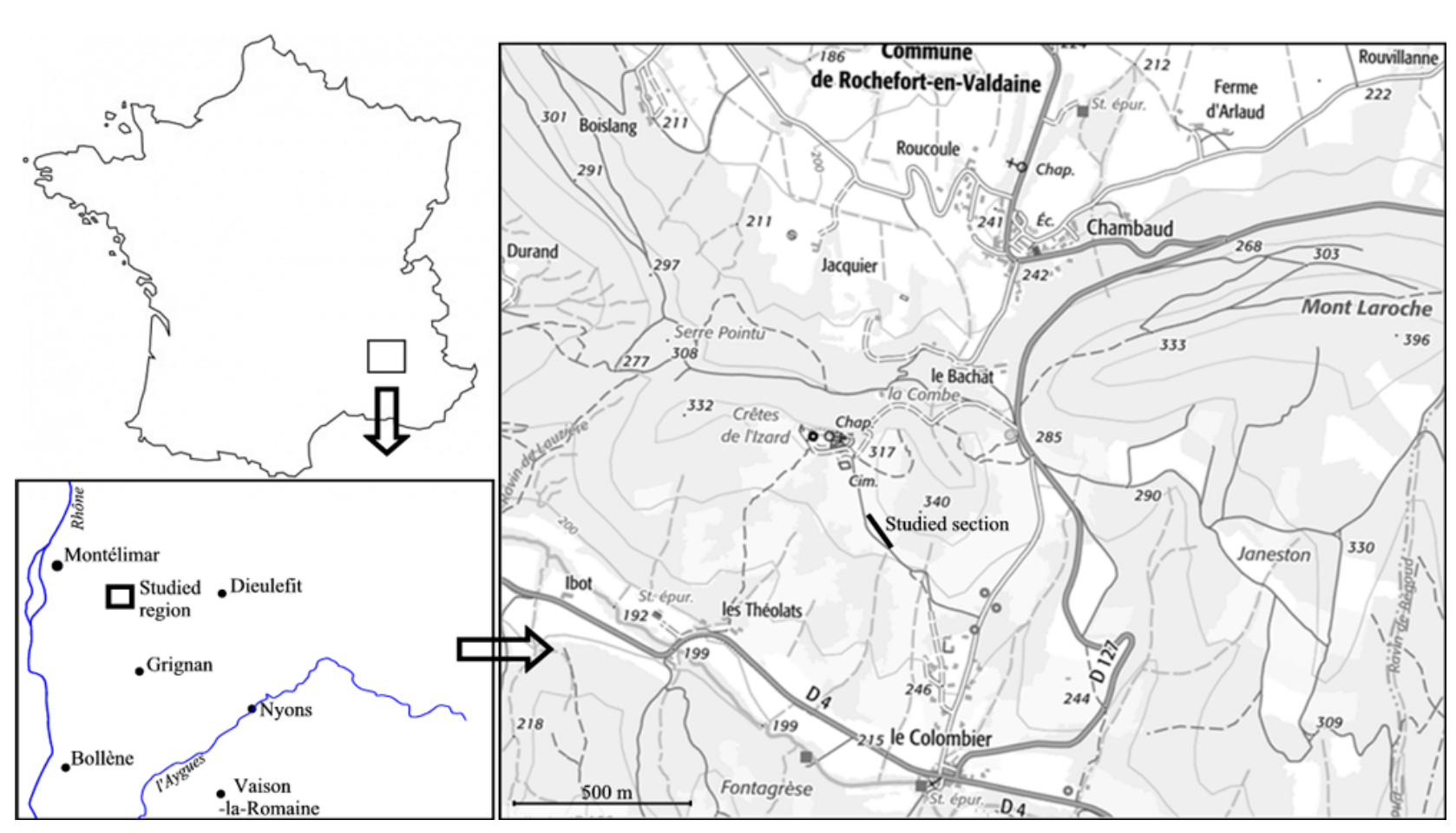

Figure 2: Geographical location of the studied section (source: www.geoportail.gouv.fr).
Ammonites indét., Hamites sp.

Austiniceras austeni (SHARPE, 1855), Schloenbachia germari (REUSS, 1845), Pachydiscus peramplus (MANTELL, 1822), Pachydiscus aff. rhodanicus ROMAN \& MAZERAN, 1913, Scaphites aff. geinitzii ORBIGNY, 1850.

Barroisiceras ? n. sp., Schloenbachia cf. albinus (FRITSCH, 1872),

Schloenbachia aff. germari (REUSS, 1845), Scaphites geinitzii ORBIGNY, 1850, Pachydiscus peramplus (MANTELL, 1822), Pachydiscus sp. juv. aff. peramplus (MANTELL, 1822), P. aff. beyrensis CHOFFAT, 1898, Prionotropis sp., Anisoceras sp.

Germariceras aff. germari (REUSS, 1845), Scaphites geinitzi ORBIGNY, 1850, Lewesiceras peramplum (MANTELL, 1822), Pseudotissotia cf. nigeriensis (WoODS, 1911).

Lewesiceras peramplus (MANTELL, 1822), Pseudotissotia (Bauchioceras) cf. nigeriensis (WoODS, 1911), Heterotissotia sp.

Neophylloceras bizonatum (FRITSCH, 1872), Gaudryceras (Gaudryceras) denseplicatum (JimBo, 1894), Lewesiceras mantelli C.W. WRIGHT \& E.V. WRIGHT, 1951, Prionocyclus cf. germari (REUSS, 1845), Neoprionocyclus vocontiensis DIEBOLD, 2012, Eubostrychoceras (Eubostrychoceras) saxonicum (SCHLÜTER, 1875), Hyphantoceras (Hyphantoceras) cf. flexuosum (SCHLÜTER, 1872), Hyphantoceras (Hyphantoceras) cf. ernsti WIESE, 2000, Sciponoceras bohemicum bohemicum (FRITSCH, 1872), Baculites undulatus OrBIGNY, 1850, Scaphites geinitzii ORBIGNY, 1850.

Vocontiiceras vocontiense DIEBOLD et al., 2018, Scaphites geinitzii ORBIGNY, 1850, Lewesiceras mantelli C.W. WRIGHT \& E.V. WRIGHT, 1951, Prionocyclus germari (REUSS, 1845), Hyphantoceras (Hyphantoceras) flexuosum (SCHLÜTER, 1872), Hyphantoceras (Hyphantoceras) ernsti WIESE, 2000, Neophylloceras bizonatum (FRITSCH, 1872), Gaudryceras cf. denseplicatum (JIMBO, 1894), Eubostrychoceras (Eubostrychoceras) saxonicum (SCHLÜTER, 1875), Baculites undulatus ORBIGNY, 1850, Sciponoceras bohemicum bohemicum (FRITSCH, 1872). 


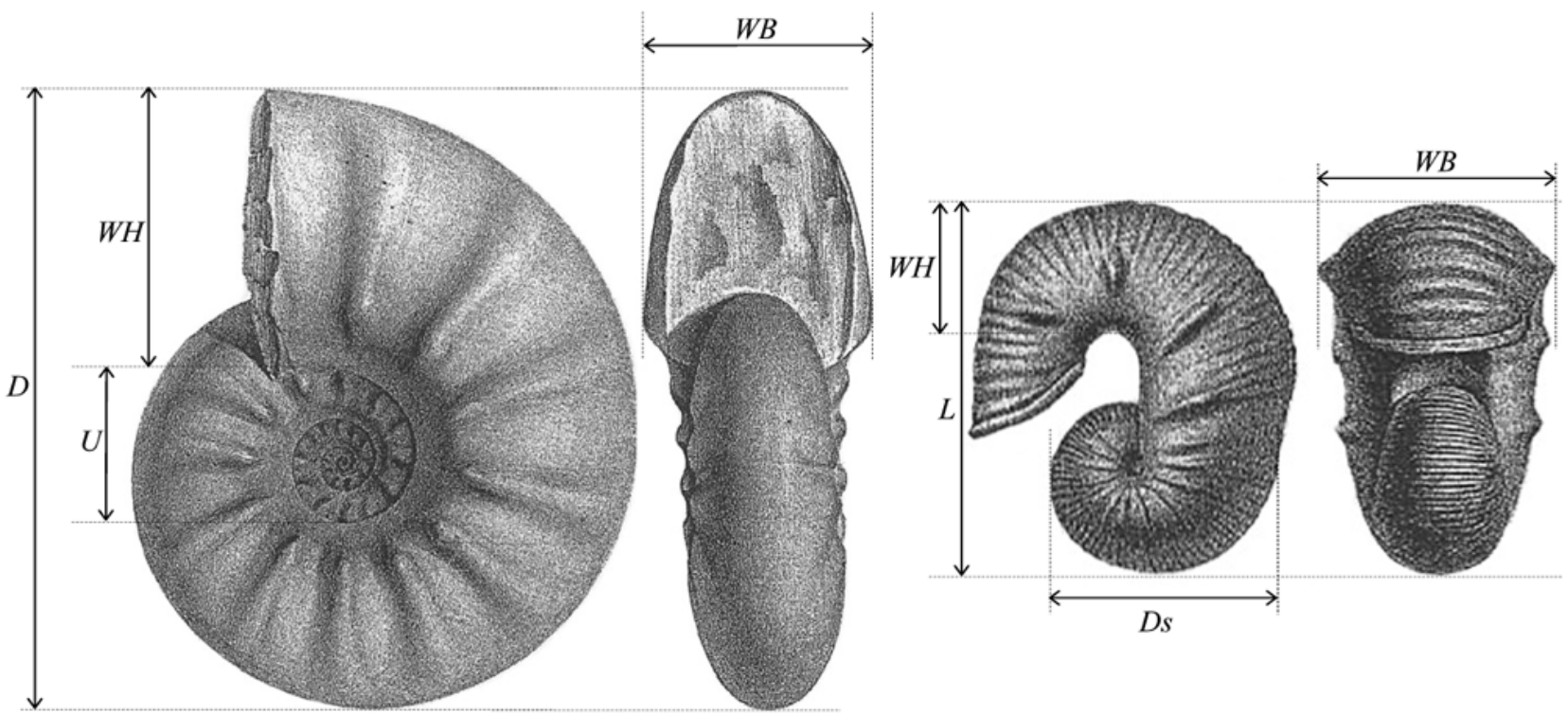

Figure 3: Explanatory scheme for the measurements made on the studied specimens (from ORBIGNY, 1840-1842, modified).

The suture lines are rarely visible and cannot be studied.

Repositories of the studied or quoted specimens are abbreviated and indicated in Table 2.

Table 2: List of abbreviations used in the text.

BGR Bundesanstalt für Geologie und Rohstoffkunde, Berlin (Germany)

BMNH British Museum of Natural History, London (England)

GBA Geologische Bundesanstalt (Wien, Austria)

MNHN Muséum National d'Histoire Naturelle (Paris, France)

MR ReQUIEN Museum (Avignon, France)

Rch BAUDOUIN coll.

The biostratigraphic scheme that is used here (Fig. 1) is the composite ammonite scale established by RoBASZYNSKI et al. (2014, Fig. 32) for the north-western Europe.

The suprageneric classification used in the paleontological study is that of C.W. WRIGHT, 1996.

\section{Paleontological and systematic study}

Order Ammonoidea ZI TTEL, 1884

Suborder Lytoceratina HYATT, 1889

\section{Superfamily Tetragonitaceae HYATT, 1900}

\section{Family Gaudryceratidae SPATH, 1927}

Genus Gaudryceras Grossouvre, 1894

(= Epigaudryceras SHIMIZU, 1934;

Hemigaudryceras SHIMIZU, 1934;

Neogaudryceras SHIMIZU, 1934;

Pseudogaudryceras SHImizu, 1934)

Type species: Ammonites mitis HAUER, 1866 [by subsequent designation of Boule et al. (1906, p. 11)].

\section{Gaudryceras mite (HAUER, 1866)}

$$
\text { (PI. 1, fig. 1) }
$$

1866. Ammonites mitis sp. nov. - HAUER, p. 305, PI. 2, figs. 3-4.

1873. Ammonites glaneggensis sp. nov. - REDTENBACHER, p. 119, Pl. 27, fig. 3.

1894. Lytoceras denseplicatum sp. nov. - JimBo, p. 182, PI. 23, fig. 1.

1895. Lytoceras (Gaudryceras) varagurense sp. nov. KoSSMAT, p. 122, Pl. 17, fig. 9; Pl. 18, fig. 2.

1910. Pachydiscus? hellichi sp. nov. - FRITSCH, PI. 5, fig. 14.

1920. Lytoceras (Gaudryceras) amapondense sp. nov. HOEPEN, p. 42, PI. 24, figs. 4-5.

? 1924. Neogaudryceras denseplicatum (JIMBo, 1894) nonstriata var. nov. - YeHARA, p. 35, PI. 2, fig. 1. 
1952. Puzosia lytoceratoides sp. nov. - HAAS, p. 8, figs. 14-17.

1962. Gaudryceras navarrense sp. nov. - WiEDMANN, p. 158, PI. 9, fig. 3.

1962. Gaudryceras vascogoticum sp. nov. - WiEDMANN, p. 159, Pl. 9, figs. 2, 6.

1979. Gaudryceras glaneggense (REDTENBACHER, 1873)

- Kennedy \& Summesberger, p. 76, PI. 3, fig. 1; PI. 4, fig. 1 (with synonymy).

1979. Gaudryceras mite (HAUER, 1866) - KENNEDY \& SummeSBERGER, p. 74, Fig. 1; PI. 1, fig. 1; PI. 2, figs. 1-2 (with additional synonymy).

? 1982. Gaudryceras ex. gr. denseplicatum (JimBo, 1894) - IMMEL et al., p. 9, Pl. 1, fig. 5.

1982. Gaudryceras mite (HAUER, 1866) - TZANKOV, p. 16 , Pl. 2, figs. 3-4.

? 1988. Gaudryceras denseplicatum (JiMBO, 1894) SzÁsz \& ION, Pl. 5, fig. 4.

1995. Gaudryceras denseplicatum (JIMBO, 1894) - MATsuмото, p. 91, Figs. 44-52, 53A, 67E-F (with additional synonymy).

? 1995. Gaudryceras denseplicatum (JimBo, 1894) KENNEDY et al., p. 390, PI. 2, figs. 1-3; PI. 3, figs. 15-16; PI. 4, figs. $12-13$

1996. Gaudryceras mite (HAUER, 1866) - SUMMESBERGER \& KENNEDY, p. 112, PI. 1, figs. 1-4 (with additional synonymy).

2000b. Gaudryceras mite (HAUER, 1866) - WIESE, p. 128 , Pl. 1, fig. 1 (with additional synonymy).

2005. Gaudryceras sp. - ANDRADE, p. 47, PI. 12, fig. 3.

2012. Gaudryceras (Gaudryceras) denseplicatum (JIMBO, 1894) - DieBolD, p. 145, Pl. 1, fig. 2.

? 2012. Gaudryceras (Gaudryceras) denseplicatum (JIMBO, 1894) - DiEBOLD, p. 201, Pl. 1, fig. 2.

2014. Gaudryceras mite (HAUER, 1866) - AMÉDRO \& DEVALQUe in ROBASZYNSKI et al., p. 130, PI. 35, fig. 1 (with additional synonymy).

2016. Gaudryceras cf. G. mite (HAUER, 1866) - RAFFI \& OliVero, p. 380, Fig. 3.1-2.

Type: The holotype by monotypy is the original of HAUER (1866, p. 305, PI. 2, figs. 3-4 GBA 1866/01/3) from the Gosau Group (Austria), possibly from the Turonian of the Ofenwand near Strobl/Weißenbach (SUmmesberger \& KenNedy, 1996).

Material $(n=1)$ : Specimen no. Rch13.

Description: Evolute shell (U/D close to $0.31)$, almost complete, the last third of whorl corresponding to the body chamber. The whorl section is suboval, with a steep and rounded umbilical wall, moderately rounded flanks and a wide and rounded ventral region.

Ornamentation is visible on the last whorl. Starting with fine, dense and flexuous rectiradiate or slightly prorsiradiate ribs, the adult ornamentation is marked by the sudden apparition of numerous groups of two or three elevated ribs, that form ridges on the flanks and ventral region where they reach their maximum strength. The ridges develop at the base of the umbilical wall. Between these groups of ribs, one or two simple and fine intercalatories occur. This ornamental stage disappears for approximately a quarter of whorl where the ornamentation is composed of simple, relatively strong ribs appearing at the base of the umbilical wall. On the last quarter of whorl, the ornamentation of ridges reappears, separated by two or three fine intercalatories.

Dimensions: Table 3: Measurements of Gaudryceras mite (HAUER, 1866).

\section{no. D $U$ WH WB U/D U/ WH WH/D WB/D WB/WH}

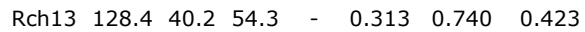

Discussion and comparisons: The ornamentation of Rch13, represented by a growth interval with fine and dense ribs followed by an interval with ribs grouped in elevated ridges, is characteristic of Gaudryceras glaneggense (REDTENBACHER, 1873), a junior synonym of Gaudryceras mite (HAUER, 1866) according to SUMMESBERGER \& KENNEDY (1996).

Gaudryceras tenuiliratum YABE, 1903, a taxon from the Coniacian to early Campanian of Japan and the Russian Far East (Sakhalin), is considered as a possible synonym of Gaudryceras denseplicatum (JIMBo, 1894) [= Gaudryceras mite (HAUER)] by IMmel et al. (1982, p. 9), due to the presence of primary ribs on the body chamber. However, the primary ribs of Gaudryceras tenuiliratum YABE are very different, far less numerous and do not correspond to groups of fine ribs as seen on the body chamber of Gaudryceras mite (HAUER). Furthermore, on the inner whorls the ornamentation of Gaudryceras tenuiliratum YABE is different, since towards the venter, the fine ribs are subdivided into numerous extremely fine riblets, characteristic absent in Gaudryceras mite (HAUER) (MATSUMOTO, 1995, p. 125). The ribbing of specimen no. Rch13 differs from $G$. tenuiliratum $\mathrm{YABE}$; this specimen is attributed to $G$. mite (HAUER), and G. tenuiliratum YABE is considered here as a different species, following the opinion of MATSUMOTO (1995).

Occurrence: Gaudryceras mite (HAUER, 1866) has a worldwide distribution and is known to range from the Turonian to the Maastrichtian (SumMESBERGER \& KENNEDY, 1996, p. 114).

Suborder Ammonitina HyATT, 1889

$$
\begin{gathered}
\text { Superfamily Desmocerataceae } \\
\text { ZITTEL, } 1895
\end{gathered}
$$

Family Desmoceratidae ZI TTEL, 1895

Subfamily Puzosiinae Spath, 1922

\section{Genus Mesopuzosia Matsumoto, 1954}

$$
\text { (= Pteropuzosia MATSUMOTO, 1988) }
$$

Type species: Mesopuzosia pacifica MATSUMoTO, 1954 [by original designation of MATSUMOTO (1954, p. 79)]. 


\section{cf. Mesopuzosia Matsumoto, 1954}

(PI. 1, fig. 2; PI. 2, fig. 1; PI. 3, fig. 1)

Material $(n=1)$ : Specimen no. Rch38.

Description: Large-sized specimen, poorly preserved and entirely septate, with moderately evolute coiling ( $U / D$ close to 0.23$)$. The whor section is subrectangular. The umbilical wall is high and vertical, with a rounded shoulder; the flanks are moderately rounded and the ventral region is narrow, widening on the last quarter of the preserved whorl.

The ornamentation, only visible on the first quarter of the last whorl, consists of fine and dense, straight, prorsiradiate ribs, bending forward towards the venter. Most ribs arise from the umbilical shoulder, but some intercalatories or bifurcated ribs appear on the outer third of the flanks. A slightly stronger rib, with the same pattern and preceded by an incipient constriction, could correspond to a primary rib.

Dimensions: Table 4: Measurements of cf. Mesopuzosia Mатsumoto, 1954.

no. $D$ D $U$ WH WB U/D U/WH WH/D WB/D WB/ WH

$\begin{array}{llllllllll}\text { Rch38 } & 255 & 58.9 & 115.1 & \text { c74 } & 0.231 & 0.512 & 0.451 & 0.290 & 0.643\end{array}$

Discussion and comparisons: The whorl dimensions, the backward flexure of the ribs and the whorl section point to a Puzosiinae SPATH, 1922, and the fact that ribs reach from the umbilicus over the flanks to the venter shows affinity with Mesopuzosia MATsumoto, 1954, and more probably with Mesopuzosia mobergi (GROSSOUVRE, 1894). However, the poor preservation of the specimen and the suture do not allow confirmation, and therefore the specimen is kept under open nomenclature.

Occurrence: The genus occurs in lower and middle latitudes from the Turonian to the Campanian (C.W. Wright, 1996; KenNedy \& GALE, 2015).

\section{Family Pachydiscidae SPATH, 1922}

\section{Genus Lewesiceras SPATH, 1939}

Type species: Ammonites peramplus MANTELL, 1822 [by original designation of SPATH (1939, p. 296)].

\section{Lewesiceras mantelli}

\section{C.W. WRIGHT \& E.V. WRIGHT, 1951}

(PI. 3, figs. 2-3; PI. 4, fig. 1; PI. 5, figs. 1-2)

pars 1849. Ammonites peramplus MANTELL, 1822 - GEINITZ, p. 116, PI. 5, figs. 1 , ? 3, non $2(=$ ? Lewesiceras sp.).

pars 1853. Ammonites peramplus MANTELL, 1822 SHARPE, p. 26, PI. 10, figs. 2-3, non 1 [= Lewesiceras peramplum (MANTELL, 1822)].

1926. Pachydiscus cricki sp. nov. - SPATH, p. 82 (non KOSSMAT, 1898).
1951. Lewesiceras mantelli sp. nov. - C.W. WRIGHT \& E.V. WRIGHT, p. 20, PI. 10, fig. 3.

1951. Lewesiceras sharpei (SPATH, 1926) - C.W. WRIGHT \& E.V. WRIGHT, p. 20, PI. 10, figs. ? 1,2

1964. Lewesiceras romani sp. nov. - SORNAY, p. 183, Figs. 1-4.

1967. Lewesiceras lenesicense sp. nov. - HoušA, p. 35 PI. 8, figs. 1-7.

1979. Lewesiceras mantelli C.W. WRIGHT \& E.V. WRIGHT, 1951 - C.W. WRIGHT, p. 310, PI. 4, figs. 1-3; PI. 6, figs. 4-5 (with synonymy).

1981. Lewesiceras mantelli C.W. WRIGHT \& E.V. WRIGHT, 1951 - KENNEDY \& C.W. WRIGHT, p. 500, PI. 75, figs. 8-11; Pl. 76, figs. 3-6.

1981. Lewesiceras mantelli C.W. WRIGHT \& E.V. WRIGHT, 1951 - C.W. WRIGHT \& KENNEDY, p. 31, PI. 2, figs. 5-6.

1982. Lewesiceras mantelli C.W. WRIGHT \& E.V. WRIGHT, 1951 - TZANKOV, p. 33, Pl. 14, figs. 2-4.

1988. Lewesiceras mantelli C.W. WRIGHT \& E.V. WRIGHT, 1951 - SzÁsz \& ION, PI. 5, fig. 2.

1988. Lewesiceras mantelli C.W. WRIGHT \& E.V. WRIGHT, 1951 - WALASZCZYK, p. 56, PI. 5, fig. 3.

1991. Lewesiceras mantelli C.W. WRIGHT \& E.V. WRIGHT, 1951 - KAPLAN, PI. 1, fig. 1.

2006. Lewesiceras mantelli C.W. WRIGHT \& E.V. WRIGHT, 1951 - KenNEDy \& JUIGNET in GaUthieR, p. 123, PI. 62 , fig. 1

2012. Lewesiceras mantelli C.W. WRIGHT \& E.V. WRIGHT, 1951 - DiebolD, p. 146, PI. 2, figs. 1-2.

2014. Lewesiceras mantelli C.W. WRIGHT \& E.V. WRIGHT, 1951 - WiLMSEN \& NAGM, p. 205, Fig. 3c.

2014. Lewesiceras mantelli C.W. WRIGHT \& E.V. WRIGHT, 1951 - AMÉDRO \& DEVALQUE in ROBASZYNSKI et al., p. 133, Pl. 34, fig. 3; PI. 37, fig. 2; Pl. 39, figs. 9-10.

2015. Lewesiceras mantelli C.W. WRIGHT \& E.V. WRIGHT, 1951 - KeNNEDY \& GALE, p. 514, figs. 5J, K, P-R.

Type: The species was introduced by C.W. WRIGHT \& E.V. WRIGHT, 1951 as nomen novum for Pachydiscus cricki SPATH, 1926 (non KosSMAT, 1898). The holotype by monotypy is the original of SHARPE (1853, PI. 10, fig. 3 as Ammonites peramplus MANTELL, 1822 - BMNH 88587), from the late Turonian of Oldbury Hill (Wiltshire, England). It was re-illustrated by KENNEDY \& C.W. WRIGHT (1981, PI. 75, figs. 10-11) and C.W. WRIGHT \& KENNEDY (1981, PI. 2, fig. 6).

Material ( $n=7)$ : Specimens no. Rch20, Rch21, Rch22, Rch24, Rch49; no. 955, 960, coll. CHATELIER.

Description: All our specimens are smallsized (diameter from 30 to $120 \mathrm{~mm}$ ) and correspond to juveniles or inner whorls of large ammonoids, except for specimen no. 955 (PI. 4, fig. 1; PI. 5, fig. 1) which is an adult. The coiling is involute throughout ontogeny (U/D close to 0.30 ), with a subrectangular whorl section, although dimensions may be affected by the crushing of specimens. The section is circular from $D=100 \mathrm{~mm}$ (specimen no. 955, PI. 4, fig. 1 ; PI. 5, fig. 1). The umbilical wall is moderately high and rounded. The flanks and the ventral region are rounded. 
The ornamentation consists of rectiradiate and slightly concave primary ribs, arising from a bulla just above the umbilical shoulder in the juvenile whorls. Up to a diameter of about $60-70 \mathrm{~mm}$, the primary ribs cross the ventral region without fading and with a slight retroverse projection. On the inner whorls, up to a diameter of 50-60 mm, secondary prorsiradiate ribs, slightly weaker than the primaries, appear on the upper third of the flanks. They cross the ventral region with the same pattern as the primaries. There are two to four secondaries intercalated between primaries. From $D=60 \mathrm{~mm}$ (specimens no. Rch20, Rch21, Rch22, 955), the primary ribs weaken and fade toward the ventral region with increasing diameter. At $D=80-100 \mathrm{~mm}$, there are approximately 10-12 primary ribs per whorl (specimens no. Rch20, PI. 3, fig. 3, and 960, PI. 5, fig. 2). On specimen no. Rch21 (PI. 3, fig. 2), the ribbing fades quickly on the flanks and is not perceptible at $D>55 \mathrm{~mm}$.

Dimensions: Table 5: Measurements of Lewesiceras mantelli C.W. WRIGHT \& E.V. WRIGHT, 1951.

\begin{tabular}{|c|c|c|c|c|c|c|c|c|c|}
\hline no. & D & U & WH & WB & U/ D & U/ WH & WH/ D & WB/D & WB/ WH \\
\hline $\operatorname{ch} 20$ & 117.8 & 34.9 & 49.3 & - & 0.296 & 0.708 & 0.419 & - & - \\
\hline $\operatorname{ch} 21$ & 77.3 & 24.1 & 30.5 & 20.6 & 0.312 & 0.790 & 95 & .266 & .675 \\
\hline $\operatorname{ch} 22$ & 87.7 & - & - & - & - & - & - & - & - \\
\hline $\operatorname{ch} 24$ & 30.4 & - & - & 14.1 & 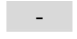 & - & - & 0.464 & - \\
\hline ch49 & 35.4 & - & - & 12.6 & - & - & 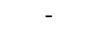 & 0.356 & 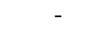 \\
\hline 955 & 194 & 64 & . & 75 & 0.330 & 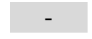 & 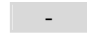 & 0.387 & 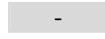 \\
\hline 960 & 82.4 & 21.5 & 28 & 3.7 & 0.261 & 0.768 & 0.340 & 0.045 & 0.132 \\
\hline
\end{tabular}

Discussion and comparisons: Lewesiceras mantelli C.W. WRIGHT \& E.V. WRIGHT, 1951, is a species close to Lewesiceras peramplum (MANTELL, 1822). Lewesiceras mantelli C.W. WRIGHT \& E.V. WRIGHT can be distinguished by its smaller adult size, wider whorl section and strong umbilical bulla. The ornamentation and the morphology of the shell of the specimens studied here correspond to Lewesiceras mantelli C.W. WRIGHT \& E.V. WRIGHT, with exception of the compressed whorl section in many specimens, probably related to compaction. The two species also have different stratigraphical ranges: Lewesiceras mantelli C.W. WRIGHT \& E.V. WRIGHT is strictly restricted to the late Turonian while Lewesiceras peramplum (MANTELL) ranges from the early to early late Turonian, with the earliest forms appearing in the latest Cenomanian (WILMSEN \& NAGM, 2013, 2014).

Lewesiceras woodi C.W. WRIGHT, 1979, is another species from the late Turonian (Holaster planus/Subprionocyclus neptuni Zone = Subprionocyclus bravaisianus Zone). On the juvenile stage, it differs from Lewesiceras mantelli C.W. WRIGHT \& E.V. WRIGHT by its lack of umbilical bullae and weaker secondary ribs.
Occurrence: Lewesiceras mantelli C.W. WRIGHT \& E.V. WRIGHT, 1951, is known to occur in the late Turonian, Romaniceras deverianum to Prionocyclus germari zones and has been reported from Ireland, England, France, Germany, the Czech Republic, Poland, Ukraine (Crimea), Russia, Kazakhstan and possibly from Austria (KenNedy \& GALE, 2015, p. 514).

\section{Superfamily Acanthoceratoidea GrossouVRE, 1894}

Family Collignoniceratidae

\section{C.W. WRIGHT \& E.V. WRIGHT, 1951}

\section{Subfamily Collignoniceratinae C.W. WRIGHT \& E.V. WRIGHT, 1951}

\section{Genus Prionocyclus Meek, 1871}

(= Germariceras BREISTROFFER, 1947)

Type species: Prionocyclus wyomingensis MEEK, 1876 [by subsequent designation of MEEK (1876, p. 452)].

\section{Prionocyclus germari (Reuss, 1845)}

$$
\text { (PI. 5, fig. 3) }
$$

1845. Ammonites Germari sp. nov. - ReUss, p. 22, PI. 7, fig. 10.

1872. Ammonites Schlönbachi sp. nov. - FRITSCH, p. 33, PI. 16, fig. 5.

1907. Schloenbachia gaudryi sp. nov. - BoulE et al., p. 16, PI. 3, fig. 1.

1947. Germariceras germari (REUSS, 1845) BREISTROFFER, without pagination.

? 1950. Schloenbachia aff. germari (ReUSS, 1845) SORNAY, p. 62.

? 1965. Prionocyclus aberrans sp. nov. - MAтsumoto, p. 25, Figs. 8-9; PI. 5, fig. 1; PI. 6, fig. 3.

1966. Prionocyclus carvaholi sp. nov. - HOWARTH, p. 224, PI. 1, figs. 8-11; PI. 2, figs. 3-6.

? 1968. Germariceras aff. germari (REUSS, 1845) MOULLADE in MidDLEMISS \& MOULLADE, p. 321.

? 1971. Prionocyclus aberrans MATSUMOTO, 1965- MATsuмото, p. 133, Fig. 3, Pl. 21, fig. 1.

1990. Prionocyclus germari (Reuss, 1845) - CobBan, p. B11, PI. 7, figs. 1-11.

? 1998. Prionocyclus cf. germari (ReUss, 1845) KüCHLER, p. 194, PI. 11, fig. 4.

2000. Prionocyclus germari (ReUSS, 1845) - ROBASZYNSKI et al., p. 402 , PI. 1 , figs. 7-8.

2001. Prionocyclus germari (ReUSS, 1845) - BRAUNBERGER \& HALL, p. 1124, PI. 3, figs. 1-18.

2001. Prionocyclus germari (REUSS, 1845) - KenNedY et al., p. 123, Figs. 108.A-B, D-F, 109-119 (with synonymy).

2003. Prionocyclus germari (ReUSS, 1845) - KENNEDY et al., p. 433, Fig. 2.

2005. Prionocyclus germari (ReUSS, 1845) - ANDRADE, p. 47, PI. 12, fig. 2.

2009. Prionocyclus germari (ReUSS, 1845) - WiESE, p. 363, Pl. 1, figs. A-J.

2012. Prionocyclus cf. germari (ReUss, 1845) - DieBold, p. 147 , Pl. 3, figs. $1-5$.

2012. Prionocyclus germari (ReUss, 1845) - DieBolD, p. 206, PI. 2, fig. 1; Pl. 3, figs. 1-3. 
2018. Prionocyclus germari (ReUSS, 1845) - DiebolD et al., Figs. $4 a-j$.

Type: The lectotype is the specimen from the "Planermergel von Werschowitz" figured by ReUSS (1845, Pl. 7, fig. 10) by subsequent designation of KenNEDY et al. (2001). It was stored in the Natural History Museum of Budapest and probably destroyed in 1953 (KAPLAN, 1988, p. 15).

Material ( $n=1)$ : Specimen no. Rch12.

Description: Our specimen, poorly preserved, shows evolute coiling ( $U / D$ close to 0.34 ) with a subquadrate whorl section that becomes gradually subrectangular. The umbilical wall is moderately high and vertical. The flanks are slightly rounded and converge towards a flat or slightly fastigiate venter, with a well-expressed and continuous keel. The juvenile ventrolateral shoulder is angular but becomes increasingly rounder during ontogeny.

On the preserved part of the inner whorls, the visible ornamentation consists of rectiradiate, straight and strong ribs that arise from an umbilical tubercle and end at a round ventrolateral tubercle. Sparse secondary ribs, weaker than the primaries, appear on the lower third of the flanks. On the last whorl, the umbilical tubercles weaken, ventrolateral tubercles disappear and the primary ribs are mainly visible on the lower half part of the flanks. The ventral area is well preserved only on the last half of the whorl and shows no ribbing.

Dimensions: Table 6: Measurements of Prionocyclus germari (REUSS, 1845).

\begin{tabular}{|c|c|c|c|c|c|c|c|c|c|} 
no. & D & U & WH & WB & U/ D & U/ WH & WH/ D & WB/ D & WB/ WH \\
\hline Rch12 & 73.7 & 24 & 32.4 & 21.5 & 0.326 & 0.741 & 0.440 & 0.292 & 0.664 \\
\hline & 106.4 & 37.2 & 41.7 & 26.7 & 0.350 & 0.892 & 0.392 & 0.251 & 0.640 \\
\hline
\end{tabular}

Discussion and comparisons: The general shape of the shell and the ornamentation of specimen no. Rch12 match well with Prionocyclus germari (REUSS, 1845) as understood by KENNEDY et al. (2001) and Wiese (2009). Prionocyclus germari (REUSS) is a rare species in Europe and the only species of this genus in the late Turonian of Europe. Prionocyclus germari (REUSS) is fairly close to Prionocyclus wyomingensis MEEK, 1876, Prionocyclus novimexicanus (MARCou, 1858) and Prionocyclus quadratus CoBBAN, 1953. These species are mainly known from the Western Interior of the United States. Prionocyclus germari (Reuss) can be distinguished from Prionocyclus wyomingensis MEEK by the absence of external ventrolateral tubercles in young specimens, and by the lack of umbilical and lateral tubercles at the adult stage. Prionocyclus germari (Reuss) differs from Prionocyclus novimexicanus (MARCOU) by more distant ribs in all ontogenenetic stages. It differs from Prionocyclus quadratus COBBAN by a higher and subrectangular section, and by the absence of lateral bullae in adult specimens (KENNEDY et al., 2001).
Furthermore, Prionocyclus germari (Reuss) has a higher stratigraphic position in the late Turonian than Prionocyclus wyomingensis MeEK, Prionocyclus novimexicanus (MARCOU) and Prionocyclus quadratus CoBban (KenNedy et al., 2001, p. 7, Fig. 3).

Occurrence: The species is known from France, Germany, the Czech Republic, Poland, Spain, Brazil, the U.S., Canada, Madagascar, Angola, Tunisia and India. Prionocyclus germari (REUSS, 1845 ) is strictly restricted to the uppermost part of the late Turonian. It is the index species of the uppermost Turonian ammonite Zone.

\section{Subfamily Barroisiceratinae BASSE, 1947}

\section{Genus Vocontiiceras \\ Di EBOLD et al., 2018}

(= Neoprionocyclus DiebolD, 2012)

Type species: Vocontiiceras vocontiense DIEBOLD et al., 2018 [by original designation of DIEBOLD et al. (2018, p. 380)].

Emended diagnosis: Involute, with subrectangular to trapezoidal whorl section; flat ventral region, becoming rounded on the body chamber. Ornamentation on the phragmocone consists of prorsiradiate primary ribs that arise from umbilical bullae and of secondary ribs. All ribs end at clavi on the ventrolateral shoulder. Body chamber smooth; continuous ventral keel throughout ontogeny.

Discussion and comparisons: Vocontiiceras DIEBOLD et al. is fairly close to Barroisiceras GrosSOUVRE, 1894, and Forresteria REESIDE, 1932, but can be distinguished from these taxa by some unequivocal characteristics. Barroisiceras GRosSOUVRE differs by its fastigiate ventral region and its crenulated keel that disappears on the body chamber, whereas in Vocontiiceras DIEBOLD et al. the ventral region is flat, rounding on the body chamber, and the keel is always continuous; Forresteria REESIDE differs by the presence of a lateral tubercle on the inner whorls and by its keel that disappears on the body chamber, whereas it persists on the body chamber of Vocontiiceras DiEBOLD et al.

In the present state of knowledge, Vocontiiceras DiEBOLD et al. is restricted to its type species, Vocontiiceras vocontiense DIEBOLD et al., 2018.

Because of the absence of inner ventrolateral tubercles and ribbing style that is very close to that of Barroisiceras GrossouvRE, 1894, Vocontiiceras DiEBold et al., 2018, clearly belongs to the subfamily Barroisiceratinae BASSE, 1947. However, DieBold et al. (2018) have attributed the species to the subfamily Collignoniceratinae C.W. WRIGHT \& E.V. WRIGHT, 1951, due to the tabulate venter and the flexure of the ventrolateral clavi. 


\section{Vocontiiceras vocontiense DieBOLD et al., 2018}

(PI. 6, figs. 1-5; PI. 7, figs. 1-4;

Pl. 8, figs. 1-5)

? 1950. Barroisiceras ? n. sp. - SORNAY, p. 62.

2012. Neoprionocyclus vocontiensis gen. nov. sp. nov. DieboLD, p. 149, PI. 4, figs. 1-6; PI. 5, figs. 1-2; PI. 6, figs. 1-2; PI. 7, figs. 1-2; PI. 8, fig. 1.

2018. Vocontiiceras vocontiense gen. nov. sp. nov. DieBOLD et al., p. 380, Figs. 40-u, 5a-f, 6a-f.

Type: The holotype is LRP REV1-33, DIEBOLD coll. by original designation of DIEBOLD et al. (2018), from the upper Turonian Prionocyclus germari Zone, upper part of bed C14 of DIEBOLD (2012) of Rochefort-en-Valdaine (Drôme, France). A cast of the holotype is stored in the Muséum National d'Histoire Naturelle (Paris, France) with the no. MNHN.F.A58223; casts of the paratype no. Rch01 and of specimens no. Rch05, Rch06 and Rch61 are stored in the REQUIEN Museum (Avignon, France) with the no. MR 2.008.326, MR 2.008.327, MR 2.008.325 and MR 2.008.324, and casts of the paratype no. Rch01 and of specimens no. Rch06 and Rch61 are stored in the Muséum National d'Histoire $\mathrm{Na}$ turelle (Paris, France) with the no. MNHN.F. A57744, MNHN.F.A57745 and MNHN.F.A57746.

Material $(n=21)$ : Specimens no. Rch01, Rch02，Rch03，Rch04，Rch05，Rch06, Rch07, Rch08, Rch09, Rch10, Rch11, Rch23a, Rch42, Rch47, Rch48, Rch54, Rch58, Rch60, Rch61, Rch62, Rch66.

Description: The coiling is involute $(U / D=$ 0.10 to 0.25 ), becoming clearly more evolute in adult specimens $(U / D \geq 0.25$ : specimens no. Rch01, PI. 6, fig. 1; no. Rch02, PI. 7, fig. 1). The whorl section is subrectangular to trapezoidal, of maximum width near the umbilical shoulder. The umbilical wall is low and vertical, with a rounded shoulder. The flanks are flat or slightly rounded and the ventral region is tabulate, with an angular ventrolateral shoulder on the phragmocone, which becomes rounded on the body chamber in adult specimens. On adult specimens the flanks and the ventral region become rounded. A welldefined continuous keel is present throughout ontogeny.

On the phragmocone, the ornamentation varies in strength and is constituted by prorsiradiate and concave ribs, of varying density (11-18 ribs per half whorl). The primary ribs appear on an umbilical bullae. Most primaries are simple, but some bifurcate mid-flank or arise pairwise from the umbilical bullae. Between each pair of primary ribs, one or two secondary ribs appear approximately at mid-flank. All ribs end in sharp clavi on the ventrolateral shoulder. The ventral keel is bordered by two smooth bands. At a highly variable diameter, commonly corresponding to the be- ginning of body chamber, all ornamental features quickly fade and the shell becomes smooth, with the exception of the persistent ventral keel.

Dimensions: Table 7: Measurements of Vocontiiceras vocontiense DIEBOLD et al., 2018.

\begin{tabular}{|c|c|c|c|c|c|c|c|c|c|}
\hline o. & D & U & $\mathbf{N H}$ & WB & U/D & U/ WH & WH/D & WB/ D & WB/ WH \\
\hline \multirow[t]{2}{*}{ Rch01 } & 116.5 & 29.2 & 53.4 & c33.5 & 0.251 & 0.547 & 0.458 & 0.288 & 0.627 \\
\hline & 80 & 16.3 & 39.3 & 23.5 & 0.204 & 0.415 & 0.491 & 0.294 & 0.598 \\
\hline \multirow[t]{2}{*}{ Rch02 } & 117.6 & 33.5 & 49.5 & c28.1 & 0.285 & 0.677 & 0.421 & 0.239 & 0.568 \\
\hline & 79.6 & 17.9 & 35.5 & 23.5 & 0.225 & 0.504 & 0.446 & 0.295 & 0.662 \\
\hline \multirow[t]{2}{*}{ Rch03 } & 66.9 & 7 & 35.5 & 16.2 & 0.105 & 0.197 & 0.531 & 0.242 & 0.456 \\
\hline & 46.7 & - & 26.1 & 13.9 & - & - & 0.559 & 0.298 & 0.533 \\
\hline Rch04 & 81.5 & 13.6 & 39.3 & - & 0.167 & 0.346 & 0.482 & - & - \\
\hline \multirow[t]{2}{*}{ Rch05 } & 59.9 & 9.8 & 30.4 & 16.3 & 0.164 & 0.322 & 0.508 & 0.272 & 0.536 \\
\hline & 42.6 & 8.2 & 22.3 & 13.2 & 0.192 & 0.368 & 0.523 & 0.310 & 0.592 \\
\hline \multirow[t]{2}{*}{ Rch06 } & 73.2 & 12.4 & 34.6 & 19.5 & 0.169 & 0.358 & 0.473 & 0.266 & 0.564 \\
\hline & 52.8 & 9 & 26.9 & 17.5 & 0.170 & 0.335 & 0.509 & 0.331 & 0.651 \\
\hline \multirow[t]{2}{*}{ Rch07 } & 88.1 & 13.2 & 46.8 & - & 0.150 & 0.282 & 0.531 & & - \\
\hline & 57.6 & 8.6 & 31.1 & c18.7 & 0.149 & 0.277 & 0.540 & 0.325 & 0.601 \\
\hline ch08 & 51.1 & - & - & c17.5 & - & - & - & 0.342 & - \\
\hline Rch09 & 31.2 & 3.6 & 16.1 & 10.5 & 0.115 & 0.224 & 0.516 & 0.337 & 0.652 \\
\hline \multirow[t]{2}{*}{ Rch10 } & 47.9 & 5.1 & 24.8 & 12.6 & 0.106 & 0.206 & 0.518 & 0.263 & 0.508 \\
\hline & 35.8 & - & 20.6 & 10.4 & - & - & 0.575 & 0.291 & 0.505 \\
\hline Rch11 & 64.6 & 6.8 & 36.6 & 13.9 & 0.105 & 0.186 & 0.567 & 0.215 & 0.380 \\
\hline Rch23a & 26 & - & 15 & 6.7 & - & - & 0.577 & 0.258 & 0.447 \\
\hline 2ch42 & 43.2 & c7.8 & 25 & c18.8 & 0.181 & 0.312 & 0.579 & 0.435 & 0.752 \\
\hline 2ch47 & 53.5 & 10.4 & 27.1 & 15.2 & 0.194 & 0.384 & 0.507 & 0.284 & 0.561 \\
\hline rch48 & 43.2 & c5.4 & 24.4 & - & 0.125 & 0.221 & 0.565 & - & - \\
\hline Rch54 & 66.7 & 10.4 & 32.4 & 14 & 0.156 & 0.321 & 0.486 & 0.210 & 0.432 \\
\hline \multirow[t]{2}{*}{ Rch58 } & 74.9 & - & 43.4 & 16.9 & - & - & 0.579 & 0.226 & 0.389 \\
\hline & 52.1 & - & 26.7 & 11 & - & - & 0.512 & 0.211 & 0.412 \\
\hline \multirow[t]{2}{*}{ Rch60 } & 60.6 & 10.1 & 31.4 & 13.7 & 0.167 & 0.322 & 0.518 & 0.226 & 0.436 \\
\hline & 39 & 9.8 & 18.3 & 12.3 & 0.251 & 0.536 & 0.469 & 0.315 & 0.672 \\
\hline \multirow[t]{2}{*}{ Rch61 } & 43.3 & 9.9 & 20.2 & 14.9 & 0.229 & 0.490 & 0.467 & 0.344 & 0.738 \\
\hline & 32.6 & 7.5 & 14.4 & 13.9 & 0.230 & 0.521 & 0.442 & 0.426 & 0.965 \\
\hline ch62 & 76.3 & - & 39.7 & - & - & - & 0.520 & 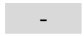 & 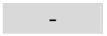 \\
\hline \multirow[t]{2}{*}{ Rch66 } & 114.6 & 25.6 & 49.8 & - & 0.223 & 0.514 & 0.435 & - & - \\
\hline & 75.7 & 13.2 & 38.3 & 20.6 & 0.174 & 0.345 & 0.506 & 0.272 & 0.538 \\
\hline
\end{tabular}

Discussion and comparisons: Vocontiiceras vocontiense Diebold et al., 2018, shows a large intraspecific variability. It affects the width of the shells (Fig. 4), the strength of the ornamentation and the ontogenetic stage at which it disappears, with a transition from compressed morphotypes (WB/WH close to 0.40: Rch11, Pl. 6, fig. 4) to stout morphotypes (WB/WH > 0.90: Rch42, PI. 6, fig. 5; Rch61, Pl. 8, fig. 5). $U / D$ and $W B / W H$ are correlated (Fig. 5) and specimens more evolute show also a greater width (Rch02, PI. 7, fig. 1; Rch61, Pl. 8, fig. 5). On gracile specimens, the ornamentation is weak, sometimes limited to ventrolateral clavi (Rch11, PI. 6, fig. 4); it also fades prematurely (at approximately $D=48 \mathrm{~mm}$ in Rch10, Pl. 8, fig. 2). On robust specimens, the ornamentation is stronger and fades between $D=$ $85 \mathrm{~mm}$ (Rch01, Pl. 6, fig. 1) to $D=110 \mathrm{~mm}$ in Rch02, where primary ribs are still present. Furthermore, rib density is variable and is higher on 


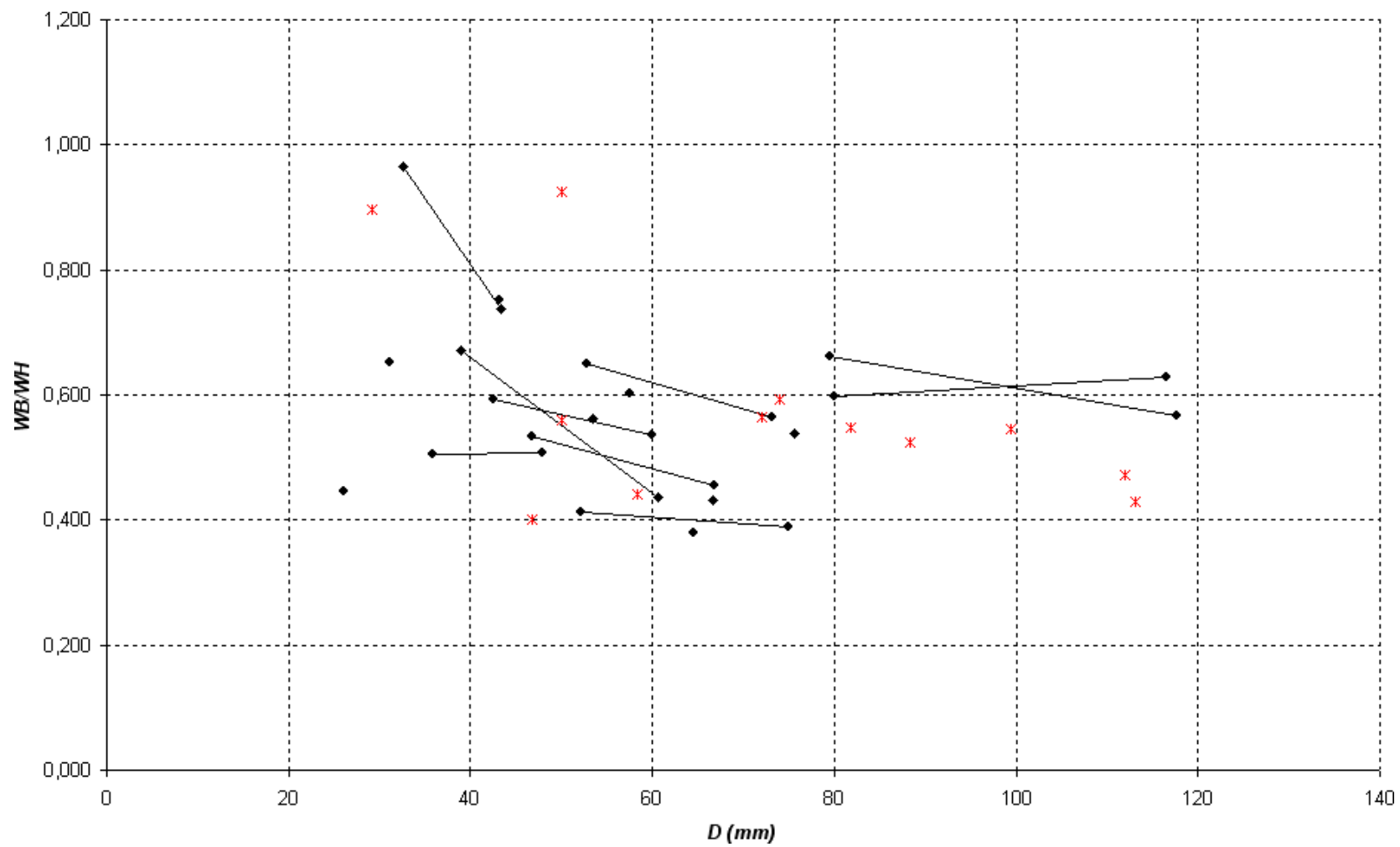

Figure 4: Bivariate diagram of the whorl shape compression $(W B / W H)$ through ontogeny $(D)$. In black diamonds, Vocontiiceras vocontiense DIEBOLD et al., 2018; in red stars, Barroisiceras haberfellneri (HAUER, 1866), data from SUMMESBERGER \& KENNEDY, 1996. Measurements taken at various diameters of the same specimen are connected with a line.

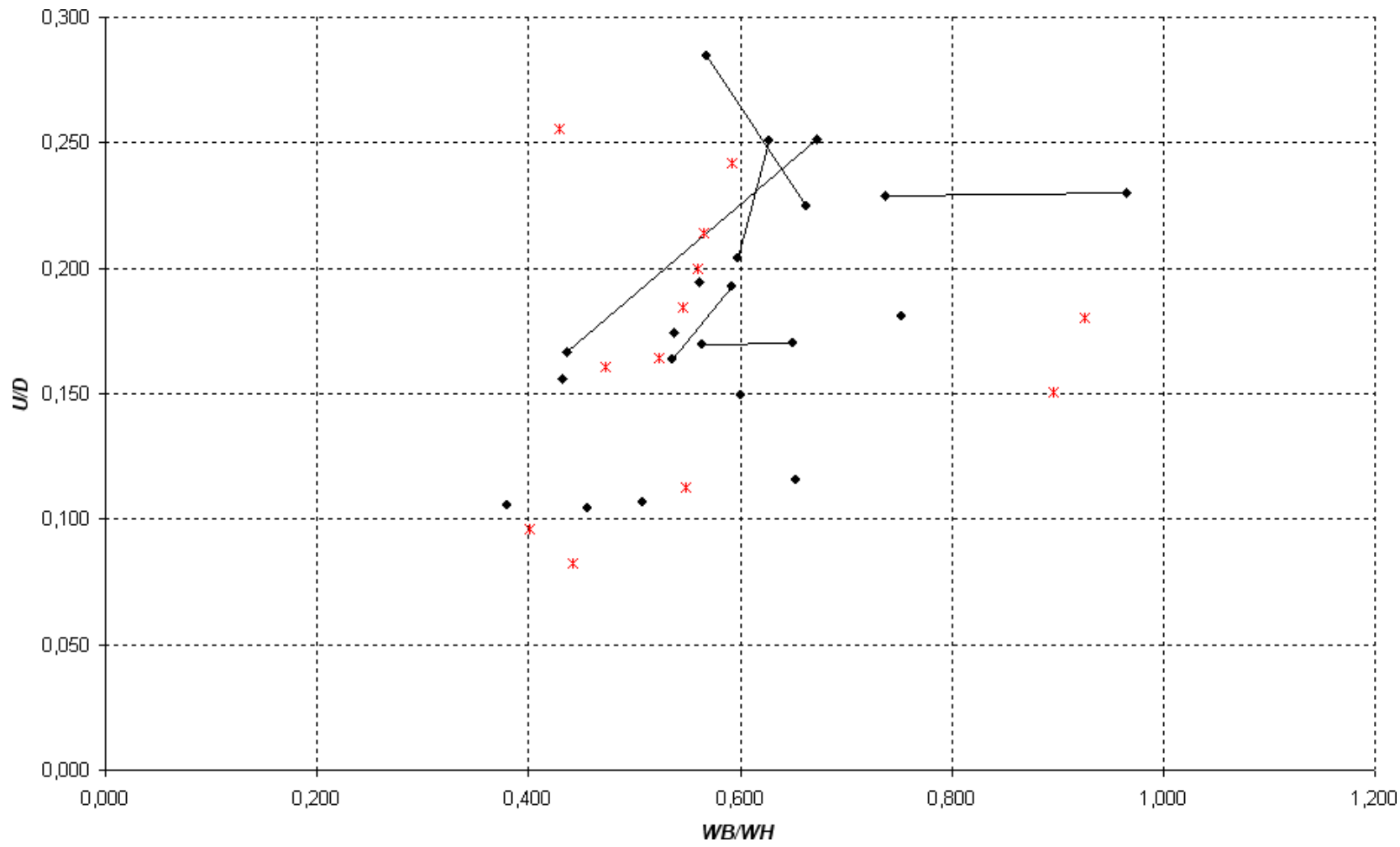

Figure 5: Bivariate diagram of the degree of involution $(U / D)$ versus the whorl shape compression $(W B / W H)$. In black diamonds, Vocontiiceras vocontiense DIEBOLD et al., 2018; in red stars, Barroisiceras haberfellneri (HAUER, 1866), data from SUMmESBERGER \& KENNEDY, 1996. Measurements taken at various diameters of the same specimen are connected with a line. 
compressed morphotypes. For example, Rch08 (PI. 6, fig. 2) shows 11 ribs per half whorl at $D=$ $51 \mathrm{~mm}$, while Rch05 (PI. 7, fig. 3) has 18 ribs per half whorl at $D=53 \mathrm{~mm}$. These patterns of morphological intraspecific variation correspond to BUCKMAN's rules of covariation (WESTERMANN 1966; MonNET et al., 2015, and references therein).

Vocontiiceras vocontiense DIEBOLD et al., 2018, shows an intraspecific variability comparable to Barroisiceras haberfellneri (HAUER, 1866) (SUMMESBERGER \& KENNEDY, 1996, p. 123).

Vocontiiceras vocontiense DIEBOLD et al. is close to Barroisiceras haberfellneri (HAUER), from the late Turonian (Prionocyclus germari Zone) of Austria. It differs by the shape of its venter and ribs ending at ventrolateral clavi in Vocontiiceras vocontiense DIEBOLD et al., while they are present on the ventral region of Barroisiceras haberfellneri (HAUER). Vocontiiceras vocontiense DIEBOLD et al. differs further by its well-defined, continuous keel throughout ontogeny, whereas it is crenulated and fading on the body chamber of Barroisiceras haberfellneri (HAUER) and all other representatives of Barroisiceras GrossouVRE, 1894.

Vocontiiceras vocontiense DIEBOLD et al. is also comparable to Barroisiceras romieuxi PERVINQUIÈRE, 1907, from the Coniacian (?) of Tunisia, known only by its phragmocone. Both species share an involute shell with a similar section and a closely spaced ribbing. Vocontiiceras vocontiense DiEBOLD et al. differs by its sharp ventrolateral clavi and continuous keel on a flat venter.

Vocontiiceras vocontiense DIEBOLD et al. presents similarities with Prionocycloceras iberiense (BASSE, 1948), a species from the late Coniacian of Spain. Despite their very similar section, ventral region, umbilical tubercles and ventrolateral clavi, Prionocycloceras iberiense (BASSE) differs by its fastigiate venter on the inner whorls, very weak ribbing throughout ontogeny and the fading of the keel on the body chamber.

Vocontiiceras vocontiense DIEBOLD et al. can easily be distinguished from Forresteria (Harleites) petrocoriensis (CoQUAND, 1859), from the latest Turonian and early Coniacian of Europe, by the lack of lateral tubercles on the inner whorls, the tabulate ventral area and the persistent and continuous keel at all growth stages.

Neoprionocyclus vocontiensis DIEBOLD, 2012, was established in an unpublished thesis. It is therefore a synonym of Vocontiiceras vocontiense DiEBOLD et al., 2018.

Occurrence: The species is only known from Rochefort-en-Valdaine (Drôme, France), in the upper part of bed c14 of DieBold (2012), late Turonian, Prionocyclus germari Zone.

\section{Suborder Ancyloceratina WIEDMANN, 1966}

\section{Superfamily Turrilitoidea GILL, 1871}

Family Nostoceratidae HYATT, 1894

Genus Hyphantoceras HYATT, 1900

Subgenus Hyphantoceras HYATT, 1900

(= Euhyphantoceras SHImIzU, 1935;

Orientoceras SHIMIZU, 1935; Ankinatsytes

COLLIGNON, 1965)

Type species: Heteroceras reussianum ORBIGNY, 1850 [by original designation of HYATT (1900, p. 587)].

\section{Hyphantoceras (Hyphantoceras) flexuosum (SCHLÜTER, 1872)}

$$
\text { (PI. 9, fig. 1) }
$$

1872. Heteroceras flexuosum sp. nov. - SCHLÜTER, p. 108 , Pl. 32, figs. 10-12.

pars 1988. Hyphantoceras flexuosum (SCHLÜTER, 1872) - KAPLAN \& SCHMID, p. 57, Pl. 13, figs. ? 1, 3-4, non $2[=$ Hyphantoceras (Hyphantoceras) ernsti WIESE, 2000].

1991. Hyphantoceras flexuosum (SCHLÜTER, 1872) KAPLAN, PI. 2, fig. 3.

1998. Hyphantoceras flexuosum (SCHLÜTER, 1872) WIESE \& KRÖGER, PI. 2, fig. 8.

2000a. Hyphantoceras flexuosum (SCHLÜTER, 1872) WIESE, p. 409, PI. 2, figs. 1-10; PI. 3, figs. 13-14.

2012. Hyphantoceras cf. flexuosum (SCHLÜTER, 1872) DieBoLD, p. 152, PI. 8, figs. 2-3.

2018. Hyphantoceras flexuosum (SCHLÜTER, 1872) DiEBOLD et al., Fig. 4m-n.

Type: The lectotype is BGR $\times 5687 a$, the original of SCHLÜTER (1872, PI. 32, figs. 10-12), designated and re-illustrated by WIESE (2000a, p. 409, PI. 2, figs. 1-3). It originates from the "Cuvieri Pläner" (i.e., the Erwitte Formation of WiESE et al. in NIEBUHR et al., 2007) of the region of Salzgitter (Lower Saxony, Germany). As discussed by WIESE (2000a, p. 410), its age could be early Coniacian.

Material $(n=1)$ : Specimen no. Rch14.

Description: Rch14 is a single whorl of a shell with open and slightly helical coiling and a circular whorl section. The last half of the whorl corresponds to the body chamber.

Ornamentation consists of 17 rectiradiate and concave primary ribs per whorl that appear on the dorsal region and thicken on the outer third of the flanks. Ribs are preceded by a weak constriction. Tuberculation of the primary ribs is mainly visible on the body chamber and consists of a row of small and rounded ventrolateral tubercles and by radially pinched lateral tubercles, both weak. Three to five finer secondary ribs are intercalated between the primaries. 
Dimensions: Table 8: Measurements of $\mathrm{Hy}$ phantoceras (Hyphantoceras) flexuosum (SCHLÜTER, 1872).

$$
\begin{array}{|r|c|c|c|c|}
\multicolumn{1}{c|}{\text { no. }} & \text { "D" } & \text { WH } & \text { WB } & \text { WB/ WH } \\
\hline \text { Rch14 } & - & 7.6 & 8 & 1.053 \\
\hline 46.3 & 12.9 & 12.7 & 0.984 \\
\hline 55.3 & 16.6 & 13.3 & 0.801 \\
\hline
\end{array}
$$

Discussion and comparisons: Rch14 matches perfectly the lectotype of Hyphantoceras (Hyphantoceras) flexuosum (SCHLÜTER, 1872) and falls into the conception of the species sensu WiESE (2000a) based on the general shape of its shell and ornamentation.

Hyphantoceras (Hyphantoceras) flexuosum (SCHLÜTER) and Hyphantoceras (Hyphantoceras) reussianum (ORBIGNY, 1850) are closely allied species with similar ribbing. The distinction between both taxa is difficult with fragmentary specimens. On more complete specimens, $\mathrm{Hy}$ phantoceras (Hyphantoceras) flexuosum (SCHLÜTER) differs by a higher apical angle of coiling, a body chamber without retroversum and weaker ornamentation. The two species also occur at slightly different stratigraphic positions in the late Turonian; Hyphantoceras (Hyphantoceras) reussianum (ORBIGNY) is a species from the Subprionocyclus bravaisianus Zone, that may still be present at the base of the Prionocyclus germari Zone, while Hyphantoceras (Hyphantoceras) flexuosum (SCHLÜTER) is only present with certainty in the lower part of the Prionocyclus germari Zone (WIESE, 2000a, p. 409, Fig. 2, and herein).

Hyphantoceras (Hyphantoceras) ernsti WIESE, 2000, can be distinguished by crioconic or weakly helicoidal coiling and a high apical angle. Furthermore, the ribbing of Hyphantoceras (Hyphantoceras) ernsti WIESE is similar to that of Hyphantoceras (Hyphantoceras) flexuosum (SCHLÜTER) on the early whorls, but later in ontogeny, the primary ribs arise in collars and become irregular while the secondary ribs tend to fade. Both species cooccur in the lower part of the Prionocyclus germari Zone.

Occurrence: Hyphantoceras (Hyphantoceras) flexuosum (SCHLÜTER, 1872) is known from Germany and now from south-eastern France. When well dated, Hyphantoceras (Hyphantoceras) flexuosum (SCHLÜTER, 1872) occurs in the late Turonian, Prionocyclus germari Zone, and is a major element of the "Heteromorph Beds" of WIESE (2000a), that caracterize the lower part of the Prionocyclus germari Zone in North Germany. The presence of the species in the early Coniacian, suggested by the stratigraphical position of the lectotype ("Cuvieri Pläner des Windmühlenberges bei Salzgitter", cf. WIESE, 2000a, p. 410) given by SCHLÜTER (1872, p. 108), lacks confirmation.

\section{Hyphantoceras (Hyphantoceras) ernsti WIESE, 2000}

\author{
(PI. 9, figs. 2-6)
}

pars 1968. Hyphantoceras reussianum (ORBIGNY, 1850) - Tröger, p. 45, Fig. 2, Pl. 1, fig. 3; non Fig. 1, non PI. 1, figs. 1-2 [= Hyphantoceras reussianum (ORBIGNY, 1850)].

pars 1988. Hyphantoceras flexuosum (SCHLÜTER, 1872) - KAPLAN \& SCHMID, p. 57, Pl. 13, fig. 2, non figs. 1, 3-4 [= Hyphantoceras (Hyphantoceras) flexuosum (SCHLÜTER, 1872)].

1995. Hyphantoceras reussianum (ORBIGNY, 1850) TRÖGER \& VOIGT, PI. 1, fig. 3.

1997. Neocrioceras aff. paderbornense (SCHLÜTER, 1872) - HORNA \& WIESE, PI. 1, figs. F-G.

1998. Neocrioceras sp. aff. paderbornense (SCHLÜTER, 1872) - WIESE \& KRÖGER, p. 270, PI. 2, fig. 7.

2000a. Hyphantoceras ernsti sp. nov. - WIESE, p. 410, Fig. 3, PI. 1, figs. 1-11; PI. 3, figs. 3, 9, 15.

2012. Hyphantoceras cf. ernsti WiESE, 2000 - DieBOLD, p. 152 , Pl. 9, figs. 1-4.

Type: The holotype is the original of TRÖGER (1968, Fig. 2 and PI. 1, fig. 1) by original designation, initially identified as Hyphantoceras reussianum (ORBIGNY, 1850) and re-figured by Wiese (2000a, Fig. 3 and PI. 1, figs. 1-3). It originates from the late Turonian, Prionocyclus germari Zone (Strehlen Formation) of DresdenBlasewitz (Saxony, Germany). It is stored without registration number in the collections of the Geological Institute of the TU Bergakademie, Freiberg (Saxony, Germany) (WIESE, 2000a, p. 410).

Material ( $n=5)$ : Specimens no. Rch16, Rch17, Rch18, Rch19, Rch51.

Description: All of our specimens are fragments of whorls, with loose crioconic or very slightly helicoidal coiling. The section is circular to oval and seems to become more compressed during ontogeny.

The ornamentation consists of prorsiradate primary ribs which strengthen during ontogeny, with small and round ventrolateral tubercles. The primary ribs originate dorsally where they are weaker than on the flanks and ventrally. Two to five secondary ribs are intercalated, and strengthen from the dorsal toward the ventral region.

Rch51 (PI. 9, fig. 3) represents a larger ontogenetic stage, with more and irregular primaries and irregularly fading secondaries.

Dimensions: Table 9: Measurements of $\mathrm{Hy}$ phantoceras (Hyphantoceras) ernsti WIESE, 2000.

\begin{tabular}{|c|c|c|c|}
\hline no. & WH & WB & WB/ WH \\
\hline Rch16 & 8.8 & - & - \\
\hline Rch17 & 7.3 & 6.1 & 0.836 \\
\hline Rch18 & 9.2 & 7.9 & 0.859 \\
\hline Rch19 & 8.7 & 6.8 & 0.782 \\
\hline Rch51 & 14.7 & 7.1 & 0.483 \\
& 10.6 & 6.1 & 0.575 \\
\hline
\end{tabular}


Discussion and comparisons: Likely due to the poor preservation of our specimens, the lateral tubercles indicated in the original description of Hyphantoceras (Hyphantoceras) ernsti WIESE, 2000 , seem to be present but are difficult to observe. The five specimens studied here match well with the original description of the species of WIESE (2000a).

Hyphantoceras (Hyphantoceras) ernsti WIESE can be distinguished from Hyphantoceras ( $\mathrm{Hy}$ phantoceras) reussianum (ORBIGNY, 1850) by its different coiling which is loosely crioconic or very slightly helicoidal while it is helicoidal with a smaller angle apical in the ORBIGNy's species. Hyphantoceras (Hyphantoceras) reussianum (ORBIGNY) also has a slightly older stratigraphical distribution, situated in the Subprionocyclus bravaisianus Zone and maybe at the base of the Prionocyclus germari Zone.

Hyphantoceras (Hyphantoceras) ernsti WIESE is close to Hyphantoceras (Hyphantoceras) flexuosum (SCHLÜTER, 1872). Differences between the two species were discussed above.

Hyphantoceras (Hyphantoceras) yabei (CoLLIGNON, 1965), from the early Coniacian of Madagascar, is a poorly known species, also close to Hyphantoceras (Hyphantoceras) ernsti WIESE. It differs essentially by its helicoidal coiling with a smaller apical angle and its stronger ribbing.

Occurrence: Hyphantoceras (Hyphantoceras) ernsti WIESE, 2000, is present in Germany and France, and likely in Kazakhstan (Mangyshlak) (WIESE, 2000a). The species is known from the late Turonian, Prionocyclus germari Zone, with special reference to the lower part of the zone ("Heteromorph Beds" of WIESE, 2000a).

\section{Family Baculitidae GI LL, 1871}

\section{Genus Sciponoceras HYATT, 1894}

(= Cyrtochilus MEEK, 1876, non JAKOWLEW, 1875; Cyrtochella STRAND, 1929)

Type species: Hamites baculoides MANTELL, 1822 [by original designation of HYATT (1894, p. 578)].

\section{Sciponoceras bohemicum bohemicum (FRITSCH, 1872)}

$$
\text { (PI. 9, figs. 7-8) }
$$

1872. Baculites faujassi LAMARCK, 1822 var. bohemica FRITSCH, p. 49, PI. 13, figs. 23-25, 29-30.

1909. Baculites baculoides MANTELL, 1822 - WANDERER, p. 61, PI. 9, fig. 2.

non 1959. Sciponoceras aff. S. bohemicum (FRITSCH 1822) - MATSUMOTO, p. 109, Figs. 7-11, Pl. 30, figs 2-3; PI. 31, fig. 4 (= Sciponoceras intermedium MATSUMOTO \& ОВATA, 1963).

1979. Sciponoceras bohemicum (FRITSCH, 1822) - C.W. WRIGHT, p. 285, PI. 1, figs. 3-5; PI. 7, figs. 10, 12 (with synonymy).
1981. Sciponoceras bohemicum bohemicum (FRITSCH, 1872) - C.W. WRIGHT \& KENNEDY, p. 116, PI. 31, fig. 9.

1984. Sciponoceras bohemicum bohemicum (FRITSCH, 1872) - KENNEDY et al., p. 42, Fig. 2 (e)-(g)

1988. Sciponoceras bohemicum (FRITSCH, 1872) - WALASZCZYK, p. 56, PI. 5, fig. 5.

1992. Sciponoceras bohemicum (FRITSCH, 1872) subsp. inc. - SANTAMARIA ZABALA, p. 236, PI. 2, fig. 7.

1992. Sciponoceras bohemicum (FRITSCH, 1872) ssp. SUMMESBERGER, p. 123, PI. 8, figs. 7-9.

1996. Sciponoceras bohemicum bohemicum (FRITSCH, 1872) - SUMmeSBERger \& KenNedY, p. 134, PI. 18, figs. 4, 26.

2001. Sciponoceras bohemicum (FRITSCH, 1872) - KLINGER \& KENNEDY, p. 258, Figs. 181, 182A-G, I-M, 183.

2012. Sciponoceras bohemicum bohemicum (FRITSCH, 1872) - Diebold, p. 153, Pl. 9, figs. 6, 8-9.

2014. Sciponoceras bohemicum (FRITSCH, 1872) WILMSEM \& NAGM, p. 233, Fig. 13k.

2015. Sciponoceras bohemicum bohemicum (FRITSCH, 1872) - KeNNEDY \& GALE, p. 519, Figs. 7K-O.

Type: The lectotype is the original of Baculites faujassi LAMARCK, 1822, var. bohemica of FRITSCH (1872, p. 49, PI. 13, fig. 25), by subsequent designation of C.W. WRIGHT (1979, p. 285). It is from the late Turonian (Prionocyclus germari Zone) of Lenesice, near Louny (Czech Republic).

Material ( $n=3)$ : Specimens no. Rch15, Rch44, Rch45.

Description: All specimens are fragments preserved on matrix, only a half of the section is visible, although deformed by compaction on specimen no. Rch45. The whorl section is elliptical.

Ornamentation is composed of low, wide and straight, strongly prorsiradiate ribs strengthening and widening to form ridges on the ventral region. On the body chamber (specimen no. Rch45), strong, widely spaced and strongly prorsiradiate primary ribs are comparable to the specimen figured by KLINGER \& KENNEDY (2001, Fig. 181E). Several shallow constrictions follow the ribs on Rch15 but are poorly preserved. On specimen no. Rch44, two shallow constrictions can be found.

Dimensions: Table 10: Measurements of Sciponoceras bohemicum bohemicum ( $\mathrm{FRITSCH}$, 1872).

\section{no. "L" WH \\ Rch15 $42.4 \quad 4.9$ \\ \begin{tabular}{l|l|l} 
Rch44 & 60 & 9.4
\end{tabular} \\ Rch45 $81.2 \quad 15.1$}

Discussion and comparisons: The three studied specimens correspond to different ontogenetic stages. Rch15 is likely a juvenile with part of the body chamber preserved, while specimens no. Rch44 and Rch45 are of larger size. Specimen no. Rch45 is represented by the end of the phragmocone and the body chamber. They are comparable to specimens illustrated in the 
literature, particularly by C.W. WRIGHT (1979) and by KLINGER \& KENNEDY (2001). Their ornamentation is identical to the one of the specimens illustrated on the Fig. 181 of KLINGER \& KENNEDY (2001).

Sciponoceras bohemicum anterius C.W. WRIGHT \& KENNEDY, 1981, from the late Cenomanian (Neocardioceras juddii Zone) differs from Sciponoceras bohemicum bohemicum (FRITSCH, 1872 ) by its flat flanks and by its ribs and constrictions that cross the venter in a very broad arch (C.W. WRIGHT \& KENNEDY, 1981, p. 115, and KENNEDY \& GALE, 2015, p. 520).

Sciponoceras intermedium MATSUMOTо \& ОвАTA, 1963, a species from the late Turonian of Japan, differs mainly from Sciponoceras bohemicum bohemicum (FRITSCH) by weaker constrictions and more numerous, weaker and more prorsiradiate ribs (MATSUMOTо \& ОвАTA, 1963, p. 27).

Sciponoceras bohemicum bohemicum (FRITSCH) is close to Sciponoceras gracile (SHUMARD, 1860), a late Cenomanian species, that differs by its more rounded section, stronger and more regularly rounded adult ribbing, and shallower constrictions on the dorsal region and the flanks (C.W. WRIGHT, 1979, p. 286).

Sciponoceras bohemicum bohemicum (FRITSCH) is also very close to the first Baculites LAMARCK, 1799, of the same age, with special reference to Baculites undulatus ORBIGNY, 1850, from which it can easily be distinguished by the presence of constrictions, that are unknown in Baculites LAMARCK, and by its stronger ribs that form ridges on the ventral region (C.W. WRIGHT, 1979, p. 287; Summesberger \& KenNedy, 1996, p. 135).

Occurrence: Sciponoceras bohemicum bohemicum (FRITSCH, 1872) is known from England, France, Germany, Northern Spain, the Czech Republic, Austria, Poland and likely from Kazakhstan (Kennedy \& GALE, 2015, p. 520). Sciponoceras bohemicum bohemicum (FRITSCH, 1872 ) is present in the late Turonian, Subprionocyclus bravaisianus Zone and Prionocyclus germari Zone. According to WILMSEN \& NAGM (2014, p. 233), the species could also be present in the early Coniacian.

Superfamily Scaphitoidea GI LL, 1871

Family Scaphitidae GI LL, 1871

\section{Subfamily Scaphitinae GI LL, 1871}

\section{Genus Scaphites PARKI NSON, 1811}

(= Anascaphites HYATT, 1900; Jahnnites HYATT, 1900; Holcoscaphites NowaK, 1911)

Type species: Scaphites equalis J. SOWERBY, 1813 [by subsequent designation of MEEK (1876, p. 145)].

\section{Scaphites geinitzii OrBI GNY, 1850}

$$
\text { (PI. 9, figs. 9-20) }
$$

? 1841. Ammonites cottae sp. nov. - RoEMER, p. 86, PI. 13, fig. 4.

1850. Scaphites geinitzii sp. nov. - ORBIGNY, p. 214.

1855. Ammonites Wiltonensis sp. nov. - SHARPE, p. 53, Pl. 23, fig. 10.

1913. Scaphites planus sp. nov. - Roman \& MAZERAN, p. 13 , Pl. 4, figs. $15-17$

1959. Scaphites geinitzi ORBIGNY, 1850 - NAIDIN \& SHIMANSKI, p. 195, PI. 7, fig. 3 .

1979. Scaphites geinitzii geinitzii ORBIGNY, 1850 - C.W. WRIGHT, p. 300, PI. 3, figs. 1-4, 6-7; PI. 7, fig. 9.

1979. Scaphites geinitzii laevior ssp. nov. - C.W. WRIGHT, p. 302, PI. 3, figs. 8-9; PI. 7, fig. 7.

1982. Scaphites geinitzi ORBIGNY, 1850 - TZANKov, p. 23, PI. 7, figs. 1-5.

1987. Scaphites geinitzii ORBIGNY, 1850 - KAPLAN et al., p. 10 , PI. 1 , figs. $1-4,6-10$; PI. 2, figs. 1-13; PI. 3, figs. 1-5, 9-11; Pl. 4, figs. 1-2, 7; PI. 6, fig. 6 (with synonymy).

1988. Scaphites geinitzi ORBIGNY, 1850 - WALASZCZYK, p. 56, Pl. 5, fig. 1.

1991. Scaphites geinitzii ORBIGNY, 1850 - KAPLAN, PI. 2, fig. 1 a.

? 1992. Scaphites (Scaphites) geinitzii OrBIGNY, 1850 SANTAMARIA ZABALA, p. 248, PI. 2, fig. 10

1998. Scaphites geinitzii ORBIGNY, 1850 - KÜCHLER, p. 194, PI. 11, fig. 7

2000. Scaphites geinitzii OrBIgNy, 1850 - ARKADIEV et al., p. 120 , Pl. 10 , figs. 5-7

2002. Scaphites geinitzii ORBIGNY, 1850 - C.W. WRIGHT \& KENNEDY, p. 218, Pl. 41, figs. 8-10.

2004. Scaphites geinitzii ORBIGNY, 1850 - WIESE \& KAPLAN, Pl. 1, fig. 2.

2012. Scaphites geinitzii OrBIGNY, 1850 - DieBolD, p. 155, Pl. 9, figs. 10-12.

2014. Scaphites geinitzii ORBIGNY, 1850 - AMÉDRO \& DEVALQUe in ROBASZYNSKI et al., p. 163, PI. 37, fig. 1 ; PI. 39, fig. 14.

2014. Scaphites geinitzi ORBIGNY, 1850 - WILMSEN \& NAGM, p. 236, PI. 13, figs. I, $\mathrm{n}$ (with additional synonymy).

? 2014. Scaphites geinitzi ORBIGNY, 1850 or Scaphites cf. kieslingswaldensis doylei C.W. WRIGHT, 1979 WILMSEN \& NAGM, PI. 13, fig. p.

2015. Scaphites geinitzii ORBIGNY, 1850 - KENNEDY \& GALE, p. 520, Figs. 7.A-B, E-H.

Type: The lectotype, by subsequent designation of C.W. WRIGHT (1979, p. 299), is the original of ORBIGNY (1850) from the late Turonian of Strehlen, near Dresden (Germany) (MNHN.F. R01235 - cat. no. 7197 of the ORBIGNY collection). Originaly described without figure, a cast of the lectotype was illustrated by C.W. WRIGHT (1979, PI. 3, fig. 1) and the original specimen was later figured by KAPLAN et al. (1987, PI. 2, fig. 3).

Material $(n=21)$ : Specimens no. Rch25, Rch26, Rch27, Rch28, Rch29, Rch30, Rch31, Rch32, Rch33, Rch34, Rch35, Rch36, Rch37, Rch50, Rch53, Rch57, Rch59, Rch63, Rch64, Rch65, Rch67.

Description: Our specimens are of rather small size, with a maximum length $(L)$ of 22 to 
$24 \mathrm{~mm}$ for the presumed microconchs; and 22-34 $\mathrm{mm}$ for the macroconchs. The coiling is very involute, with a narrow umbilicus and a circular whorl section. On the proversum, the height of the whorl quickly increases. This is typical of the macroconch specimens where the dorsal swelling at the beginning of the proversum hides a part of the spire. At that stage, the whorl section becomes oval. Whorl width reaches its maximum on the middle of the flexus. On the retroversum, the height of the whorl decreases and the section becomes circular again.

The spire is ornamented by radial, straight, strong primary ribs that bifurcate or trifurcate at about the mid-flank, forming secondary ribs which cross the ventral region. Occasionally secondary ribs are intercalated. On the proversum, the ornamentation strengthens and the furcation point of the ribs moves gradually towards the outer third of the flanks. At the edge of the proversum and on the flexus, the furcation point of the ribs is situated on the ventrolateral shoulder and bears a tubercle of variable strength. On the retroversum, tubercles and primary ribs vanish and the ornamentation is reduced to fine ribs on the upper half of the flanks and the ventral region. The peristome on Rch50 (PI. 9, fig. 15) shows a deep constriction.

Dimensions: Table 11: Measurements of Scaphites geinitzii ORBIGNY, 1850.

\begin{tabular}{|c|c|c|c|c|c|c|c|} 
no. & L & Ds & WH & WB & Ds/ L & WH/ L & WB/ L \\
\hline Rch25 & 32.1 & 17.7 & 12.7 & 11.4 & 0.551 & 0.396 & 0.355 \\
\hline Rch26 & 25.3 & 15.8 & 11.5 & 10.4 & 0.625 & 0.455 & 0.411 \\
\hline Rch27 & 25.4 & 17.6 & 9.7 & 8.7 & 0.693 & 0.382 & 0.343 \\
\hline Rch28 & 23.9 & - & - & - & - & - & - \\
\hline Rch29 & 31.3 & 17.2 & 11.3 & - & 0.550 & 0.361 & - \\
\hline Rch30 & 28 & 18.2 & 13.1 & 7.4 & 0.650 & 0.468 & 0.264 \\
\hline Rch31 & 28.7 & 21 & 9.9 & 8.3 & 0.732 & 0.345 & 0.289 \\
\hline Rch32 & 25.5 & 18 & 11.6 & 8.8 & 0.706 & 0.455 & 0.345 \\
\hline Rch33 & 29.6 & 23.5 & 11.1 & 6.7 & 0.794 & 0.375 & 0.226 \\
\hline Rch34 & 23 & 15.6 & 9.5 & - & 0.678 & 0.413 & - \\
\hline Rch35 & 22.3 & 13.6 & 9.1 & 7 & 0.610 & 0.408 & 0.314 \\
\hline Rch36 & 27.7 & 19.9 & 11.5 & 8.9 & 0.718 & 0.415 & 0.321 \\
\hline Rch37 & 30.3 & 15.2 & 12.9 & 7.9 & 0.502 & 0.426 & 0.261 \\
\hline Rch50 & 23.7 & 17.9 & 10 & 8.3 & 0.755 & 0.422 & 0.350 \\
\hline Rch53 & 34.1 & 20.9 & 13 & 10.6 & 0.613 & 0.381 & 0.311 \\
\hline Rch57 & 24.1 & 13.5 & 10.4 & 6 & 0.560 & 0.432 & 0.249 \\
\hline Rch59 & 24.9 & 16.8 & 9.1 & 6.8 & 0.675 & 0.365 & 0.273 \\
\hline Rch63 & 21.7 & 15.9 & 10.1 & 6.1 & 0.733 & 0.465 & 0.281 \\
\hline Rch64 & 23 & 15.6 & - & 5.4 & 0.678 & - & 0.235 \\
\hline Rch65 & 23.3 & 14.2 & 9.8 & - & 0.609 & 0.421 & - \\
\hline Rch67 & 32.9 & 17 & 14.1 & 9.4 & 0.517 & 0.429 & 0.286 \\
\hline
\end{tabular}

Discussion and comparisons: Most of the studied specimens are macroconchs, characterized by rapid increase in $W H$ on the proversum. Despite their poor preservation, Rch35 (PI. 9, fig. 20) and Rch57 (PI. 9, fig. 19) are interpreted as microconchs, due to their smaller size, their umbilicus which seems more evolute and their lower increase of $\mathrm{WH}$ on the proversum. By their general shape of the shell and their ornamentation, all specimens agree with the description of the species Scaphites geinitzii OrBIGNY, 1850, sensu KAPLAN et al. (1987), particularly the ornamentation of the spire with distinct primary and secondary ribs and lack of tubercles.

Scaphites planus RomAN \& MAZERAN, 1913, a species that is only known by its poorly preserved type-specimens from the late Turonian, Subprionocyclus bravaisianus Zone of Uchaux (Vaucluse, France), is considered as a junior synonym of Scaphites geinitzii ORBIGNY by AMÉDRO \& DeVAlque in Robaszynski et al. (2014). We follow this opinion herein.

Scaphites kieslingwaldensis LANGENHAN \& GRUNDEY, 1891, a species from the Coniacian of Europe and Madagascar, differs from Scaphites geinitzii ORBIGNY by its more evolute tuberculated spire, the higher furcation point of its ribs, and the presence of clavate tubercles on the proversum and the flexus (KAPLAN et al., 1987, p. 12).

Scaphites diana C.W. WRIGHT, 1979, is a species mostly known from the late Turonian, Subprionocyclus bravaisianus Zone, but is still present beneath the Turonian/Coniacian boundary and at the base of the Forresteria petrocoriensis Zone of the early Coniacian in northwest Germany (KAPLAN et al., 1987). It differs by its more evolute spire, more numerous and sharper ventrolateral tubercles, and more rectangular whorl section on the proversum and on the retroversum (KAPLAN et al., 1987, p. 17).

Scaphites warreni MEEK \& HAYDEN, 1860, Scaphites ferronensis COBBAN, 1951, Scaphites whitfieldi COBBAN, 1951, Scaphites nigricollensis COBBAN, 1951, and Scaphites corvensis COBBAN, 1951 , constitute a late Turonian lineage that is endemic to the Western Interior of the United States. Scaphites geinitzii ORBIGNY differs from these by its more involute spire, bulged proversum and by the highly differentiated ribbing pattern of its spire where there is a greater number of secondary ribs. Furthermore, in the North American species, the primary ribs are less numerous and more widely spaced on the proversum and the flexus, and do not bear ventrolateral tubercles.

Occurrence: Scaphites geinitzii ORBIGNY, 1850, is known from southern England, France, Germany, Poland, Czech Republic, northwestern Spain, Bulgaria, Romania, Ukraine (Crimea, Donbass), Kazakhstan, Turkmenistan and Greenland (KenNedY \& GALE, 2015, p. 521). Occurrences of Scaphites geinitzii ORBIGNY, 1850, are reported from the middle and late Turonian, early Coniacian, and likely middle Coniacian (C.W. WRIGHT, 1979, p. 300). 


\section{Conclusions}

The ammonoid fauna from Rochefort-en-Valdaine (Drôme, France) studied here is composed of Gaudryceras mite (HAUER, 1866), cf. Mesopuzosia MATSUMOTO, 1954, Lewesiceras mantelli C.W. WRIGHT \& E.V. WRIGHT, 1951, Prionocyclus germari (REUSS, 1845), Vocontiiceras vocontiense DiEBold et al., 2018, Hyphantoceras (Hyphantoceras) flexuosum (SCHLÜTER, 1872), Hyphantoceras (Hyphantoceras) ernsti WIESE, 2000, Sciponoceras bohemicum bohemicum (FRITSCH, 1872), and Scaphites geinitzii OrBIGNY, 1850. These records confirm that the Prionocyclus germari Zone is also present in south-eastern France.

Vocontiiceras vocontiense DIEBOLD et al., 2018 , is only known from Rochefort-en-Valdaine and potentially represents an endemic species. It was shown here that it has closer affinities to the Barroisiceratinae BASSE, 1947, than to the Collignoniceratinae C.W. WRIGHT \& E.V. WRIGHT, 1951. It shows the same whorl section, ornamentation of the flanks and intraspecific variability as in the genus Barroisiceras GROSSOUVRE, 1894, but differs by its flat venter and continuous keel present on the complete shell. Its morphological and ornamental similarities with Barroisiceras haberfellneri (HAUER, 1866) suggest a close relationship between these two species, that will only be elucidated by the discovery and study of a more abundant and well-horizoned material.

The occurrence at Rochefort-en-Valdaine of Prionocyclus germari (REUSS, 1845), Hyphantoceras (Hyphantoceras) flexuosum (SCHLÜTER, 1872) and Hyphantoceras (Hyphantoceras) ernsti WIESE, 2000, taxa essentially known in Germany, allows correlation of the French fauna studied herein with the German "Heteromorph Beds" of WIESE (2000a, Fig. 2), that characterize the lower part of the Prionocyclus germari Zone. Our study also shows that, despite numerous previous works, the late Turonian of south-eastern France remains relatively poorly known and requires further studies. The current work is a step forward in our understanding of the latest Turonian ammonoids of France.

\section{Acknowledgments}

We warmly thank Herbert SummesbeRger ( $\mathrm{Na}$ turhistorisches Museum, Vienna, Austria), KarlArmin TRÖGER (Bergakademie Freiberg, Geological Institute, Germany), Frank HoRNA (Sächsisches Staatsministerium für Umwelt und Landwirtschaft, Dresden, Germany), Ulrich KAPLAN (Gütersloh, Germany), Federico KRAUSE (Department of Geoscience, University of Calgary, Alberta, Canada), Eugen GRĂDINARU (Department of Geology, Faculty of Geology and Geophysics, University of Bucharest, Romania), Frank WIESE (Department of Geobiology, Georg-August University of Göttingen, Germany), Mickael RoGov (Geologi- cal Institute, Russian Academy of Sciences, Moscow, Russia), Antoine PICTET (Institute of Earth Sciences, Lausanne, Switzerland) and Bertrand MATRION (Troyes, France) to have supplied us a part of the bibliography. We warmly thanks Hervé CHATELIER (Betton, France) to have supplied us some additional material. We particularly wish to thank Luc G. BuLot (Aix-Marseille University, France) for his help during the preparation of this work. We also warmly thank our reviewers Markus WILMSEN (Senckenberg Naturhistorische Sammlungen, Dresden, Germany) and Claude MonNet (Université de Lille, Sciences et Technologies, France) for their constructive remarks and their help, Leilani RAPAPORT (Japan) and Simon MITCHELL (University of the West Indies, Kingston, Jamaica) for the improvement of the English text.

\section{Bibliographic references}

Amédro F., Badillet G. \& Devalque Ch. (1983).Biostratigraphie et biozonation des ammonites du Turonien français.- Mémoires du Muséum national naturelle, $C$, Sciences de la Terre, Entretiens du Muséum, Colloque sur le Turonien, Paris, t. 49, p. 167-173.

Amorosi A. (2012).- The occurrence of glaucony in the stratigraphic record: distribution patterns and sequence-stratigraphic significance.International Association of Sedimentologists, Special Publications, Gent, vol. 45, p. 37-54.

ANDRADE E.J. (2005, unpublished).- Turonian inoceramids and biostratigraphy of the Sergipe Basin, northeastern Brazil: An integrated study of the Votorantim and Nassau quarries.Institut für Geowissenschaften, Heidelberg University, Thesis, $155 \mathrm{p}$.

ArkadieV V.V., Atabekian A.A., Baraboshinin E.Y. \& BogdANOVA T.N. (2000).- Stratigraphy and ammonites of Cretaceous deposits of South-West Crimea.- Palaeontographica Abteilung $A$, Stuttgart, Band 255, Lfg. 4-6, p. 85-128.

Boule M., Lemoine P. \& Thévenin A. (1906-1907).Paléontologie de Madagascar. III. Céphalopodes crétacés des environs de Diego-Suarez.Annales de Paléontologie, Paris, t. 1, fasc. 4, p. $173-192$; t. 2, fasc. 1, p. 1-56.

Braunberger W.F. \& HALl R.L. (2001).- Ammonoid faunas from the Cardium Formation (Turonian-Coniacian, Upper Cretaceous) and contiguous units, Alberta, Canada: II. Collignoniceratidae and Placenticeratidae.- Canadian Journal of Earth Sciences, Ottawa, vol. 38, p. 1117-1128.

BREISTROFFER M. (1947).- Note de nomenclature paléozoologique. I. Ammonites jurassiques et crétacées.- Procès-Verbaux Mensuels de la Société Scientifique de Dauphiné, Grenoble, $26^{\text {ème }}$ année, no. 195, 5 p.

CobBan W.A. (1990).- Ammonites and some characteristic bivalves from the Upper Cretaceous Frontier Formation, Natrona County, Wyo- 
ming.- U.S. Geological Survey Bulletin, Reston, no. 1917-B, 13 p.

Devalque C., Amédro F., Philip J. \& Robaszynski F. (1983).- État des corrélations litho- et biostratigraphiques dans le Turonien supérieur des massifs d'Uchaux et de la Cèze. Les zones d'ammonites et de rudistes.- Mémoires du Muséum national naturelle, $C$, Sciences de la Terre, Entretiens du Muséum, Colloque sur le Turonien, Paris, t. 49, p. 57-69.

DieBold F. (2012, unpublished).- Systematics, biostratigraphy and biogeography of the ammonoid family Collignoniceratidae across the Turonian-Coniacian (Cretaceous) boundary in the West European and Indo-Malgach provinces.- Ruprecht-Karls-Universität, Heidelberg, Thesis, $289 \mathrm{p}$.

Diebold F., Bengtson P., Baudouin C., Lees J.A. \& BERT D. (2018).- Vocontiiceras vocontiense nov. gen. et sp. (Collignoniceratidae, Ammonoidea) from the upper Turonian (Cretaceous) Prionocyclus germari Zone of the Vocontian Basin, France.- Cretaceous Research, vol. 88, p. 375-383.

FALLOT J.-E. (1885).- Étude géologique sur les étages moyens et supérieurs du terrain Crétacé dans le Sud-Est de la France.- Annales des Sciences géologiques, Paris, vol. 18, 268 p.

FARAUD M. (1934).- Le Ligérien de la colline de Bernon près de Tresques (Gard).- Bulletin de la Société d'Étude des Sciences naturelles de Vaucluse, Avignon, no. 1, p. 11-21.

FARAUD M. (1936).- Sur deux ammonites du Turonien des environs de Bagnols-sur-Cèze.- Bulletin de la Société d'Étude des Sciences naturelles de Vaucluse, Avignon, no. 1, p. 9-17.

FARAUD M. (1940).- Le genre Vascoceras dans le Turonien du Gard.- Bulletin de la Société d'Étude des Sciences naturelles de Vaucluse, Avignon, no. 3-4, p. 3-24.

FARAUD M. (1951).- La famille des Tissotiidae dans le Turonien inférieur du Gard.- Bulletin de la Société géologique de France ( $6^{\mathrm{e}}$ série), Paris, vol. 1 , no. $1-3$, p. 147-157.

FRITSCH A. (1872).- Cephalopoden der böhmischen Kreideformation.- Verlag des Verfassers - In Commission bei Fr. Řivnáč, Prague, $51 \mathrm{p}$.

FRITSCH A. (1910).- Miscellanea Palaeontologica. 2 Mesozoica.- Selbstverlag - In Commission bei Fr. Řivnáč, Prague, 25 p.

GAUTHIER H., avec la collaboration de BUSNARDO R., Combemorel R., Delanoy G., Fischer J.-C., GueRin-Franiatte S., Joly B., KenNedy W.J., SORnAY J. \& TintANT H. (2006).- Révision critique de la Paléontologie française d'Alcide d'OrBIGNY, volume IV: Céphalopodes crétacés.- Backhuys Publishers, Leiden, $292 \mathrm{p}$.

GeINITZ H.B. (1849).- Das Quadersandsteingebirge oder Kreidegebirge in Deutschland.- Craz \& Gerlach, Freiberg, 292 p.
HAAS O. (1952).- Some Albian desmoceratid and lytoceratid ammonites from Angola.- American Museum Novitates, New York, no. 1561, 17 p.

HAUER F. von (1866).- Neue Cephalopoden aus den Gosaugebilden der Alpen.- Sitzungsberichte der Kaiserlichen Akademie der Wissenschaften in Wien, Band 53, p. 300-308.

HOEPEN E.C.N. van (1920).- Description of some Cretaceous ammonites from Pondoland.- $A n$ nals of the Transvaal Museum, Pretoria, vol. 7, p. 142-147.

HORNA F. \& WIESE F. (1997).- Stratigraphy of a Middle/Upper Turonian succession at the abandoned Hoppenstedt limestone quarry (northern Germany) and its correlation to adjacent areas.- Freiberger Forschungshefte, Band C468, p. 171-192.

Houša V. (1967).- Lewesiceras SPATH (Pachydiscidae, Ammonoidea) from the Turonian of Bohemia.- Sborník geologických věd, Paleontologie, Prague, sv. 9, p. 7-50.

HOWARTH M.K. (1966).- A mid-Turonian ammonite fauna from the Moçâmedes desert, Angola.Garcia de Orta, Revista da Junta de Investigações do Ultramar, Lisbon, vol. 14, no. 2, p. 217-227.

HYATT A. (1894).- Phylogeny of an acquired characteristic.- Proceedings of the American Philosophical Society, Philadelphia, vol. 32, no. 143, p. 349-647.

HyATT A. (1900).- Cephalopoda. In: ZitTEL K.A., Textbook of Palaeontology.- Macmillan and co., Ltd, New York, p. 502-604.

Immel H., KLinger H.C. \& Wiedmann J. (1982).- Die Cephalopoden des Unteren Santon der Gosau von Brandenberg/Tirol, Österrich.- Zitteliana, Munich, vol. 8, p. 3-32.

Jimbo K. (1894).- Beiträge zur Kenntniss der Fauna der Kreideformation von Hokkaido.- Palaeontologische Abhandlungen, Jena, Band 2, Heft 3, p. 149-194.

Jolet P., Philip J., Cecca F., Thomel G., Lopez G., TRONCHETTI G. \& BABINOT J.-F. (2001).- Integrated platform/basin biostratigraphy of the Upper Cenomanian-Lower Turonian in Provence (SE France).- Geobios, Villeurbanne, vol. 34, no. 2, p. 225-238.

KAPLAN U. (1988).- Die Ammoniten-Subfamilie Collignoniceratinae WRIGHT \& KENNEDY 1951 aus dem Turon (Ober-Kreide) von Westfalen und Niedersachsen (NW-Deutschland).- Geologie und Paläontologie in Westfalen, Münster, Heft 12, p. 5-45.

KAPLAN U. (1991).- Zur Stratigraphie der tiefen Oberkreide im Teutoburger Wald (NWDeutschland), Teil 2: Turon und Coniac im Steinbruch des Kalkwerks Foerth, Halle, Westfalen.- Bericht des Naturwissenschaftlicher Verein für Bielefeld und Umgegend, Bielefeld, Band 32, p. 125-159. 
KAPLAN U. \& KenNedY W.J. (1996).- Upper Turonian and Coniacian ammonite stratigraphy of Westphalia, NW Germany.- Acta Geologica Polonica, Warsaw, vol. 46, no. 3-4, p. 305-352.

KAPLAN U., KENNEDY W.J. \& WRIGHT C.W. (1987).Turonian and Coniacian Scaphitidae from England and northwestern Germany.- Geologische Jahbuch, Hannover, Band A103, p. 539.

KAPLAN U. \& SCHMID F. (1988).- Die heteromorphen Ammoniten der Gattungen Eubostrychoceras und Hyphantoceras aus dem Turon NWDeutschlands.- Geologie und Paläontologie in Westfalen, Münster, Heft 12, p. 47-87.

KENNEDY W.J. (1994).- Lower Turonian Ammonites from Gard (France).- Palaeopelagos Special Publication, Roma, no. 1, p. 255-275.

KENNEDY W.J., AMÉdRO F., BADILLET G., HANCOCK J.M. \& WRIGHT C.W. (1984).- Notes on Late Cenomanian and Turonian Ammonites from Touraine, Western France.- Cretaceous Research, vol. 5, p. 29-45.

Kennedy W.J., Bilotte M. \& Melchior P. (1995).Ammonite faunas, biostratigraphy and sequence stratigraphy of the Coniacian-Santonian of the Corbières (NE Pyrénées).- Bulletin des Centres de Recherches ExplorationProduction elf-Aquitaine, Pau, vol. 19, no. 2, p. 377-499.

KenNedy W.J., CobBan W.A. \& Landman N.H. (2001).- A revision of the Turonian members of the ammonite subfamily Collignoniceratinae from the United States Western Interior.- Bulletin of the American Museum of Natural History, New York, no. 267, 148 p.

Kennedy W.J. \& GALE A.S. (2015).- Late Turonian ammonites from Haute-Normandie, France.Acta Geologica Polonica, Warsaw, vol. 65, no. 4, p. 507-524.

Kennedy W.J., Phansalkar V.G. \& Walasczcyk I. (2003).- Prionocyclus germari (ReUss, 1845), a Late Turonian marker fossil from the Bagh Beds of central India.- Cretaceous Research, vol. 24 , p. $433-438$.

KenNedy W.J. \& SUMmesberger H. (1979).- A revision of Ammonites mitis HAUER and Ammonites glaneggensis REDTENBACHER from the Gosau Beds (Upper Cretaceous) of Austria.- Beiträge zur Paläontologie von Österreich, Wien, Band 6, p. 71-87.

KENNEDY W.J. \& WALASZCZYK I. (2004).- Forresteria (Harleites) petrocoriensis (CoQUAND, 1859) from the Upper Turonian Mytiloides scupini Zone of Słupia Nadbrzeżna, Poland.- Acta Geologica Polonica, Warsaw, vol. 54, no. 1, p. 55-59.

KenNedY W.J. \& WRight C.W. (1981).- Desmoceratacean Ammonites from the type Turonian.Paleontology, London, vol. 24, part 3, p. 493506.
KLINGeR H.C. \& KenNedy W.J. (2001).- Stratigraphic and geographic distribution, phylogenetic trends and general comments on the ammonite family Baculitidae GILL, 1871 (with an annotated list of species referred to the family).Annals of the South African Museum, Cape Town, vol. 107, part 1, 290 p.

KosSMAT F. (1895).- Untersuchungen über die Südindische Kreideformation, Erster Theil.Beiträge zur Paläontologie und Geologie Österreich-Ungarns und des Orients, Wien, Band 9, p. 97-203.

KÜCHLER T. (1998).- Upper Cretaceous of the Barranca (Navarra, northern Spain); integrated litho-, bio- and event stratigraphy. Part I: Cenomanian through Santonian.- Acta Geologica Polonica, Warsaw, vol. 48, no. 2, p. 157236.

Letourneur J. \& Porthault B. (1966).- Le Cénomanien et le Turonien du synclinal d'Eygaliers (Baronnies, Drôme).- Travaux du Laboratoire de Géologie de la Faculté des Sciences de I'Université de Grenoble, t. 42, p. 127-139.

Matsumoto T. (1954).- Family Puzosiidae from Hokkaido and Saghalien.- Memoirs of the Faculty of Science, Kyushu University, Fukuoka, D, vol. 5, issue 2, p. 69-118.

Matsumoto T. (1959).- Upper Cretaceous Ammonites of California, part I.- Memoirs of the Faculty of Science, Kyushu University, Fukuoka, D, vol. 8, issue 4, p. 91-171.

MAtsumoto T. (1965).- A monograph of the Collignoniceratidae from Hokkaido. Part 1.- Memoirs of the Faculty of Science, Kyushu University, Fukuoka, D, vol. 16, issue 1, p. 1-80.

Matsumoto T. (1971).- A monograph of the Collignoniceratidae from Hokkaido. Part 5.- Memoirs of the Faculty of Science, Kyushu University, Fukuoka, D, vol. 21, issue 1, p. 129162.

Matsumoto T. (1995).- Notes on Gaudryceratid Ammonites from Hokkaido and Sakhalin.Palaeontological Society of Japan, Tokyo, special papers, no. 35, $152 \mathrm{p}$.

MATSUMOTO T. \& OвAтA I. (1963).- A monograph of the Baculitidae from Japan.- Memoirs of the Faculty of Science, Kyushu University, Fukuoka, D, vol. 13, issue 1 , p. 1-116.

MeEK F.B. (1876).- A report on the invertebrate Cretaceous and Tertiary fossils of the Upper Missouri Country.- Report of the United States Geological and Geographical Surveys of the Territories, Washington, vol. 9, 629 p.

MenNESSIER G. (1950).- Monographie géologique du Massif d'Uchaux.- Bulletin des Services de la Carte géologique de la France et des Topographies souterraines, Paris, no. 227, 50 p.

MiddLEMISS F.A. \& Moullade M. (1968).- Summer field meeting in the South of France between Lyon and Avignon.- Proceedings of the Geologists' Association, London, vol. 81, issue 2, p. 
302-361.

Monnet C., De Baets K. \& Yacobucci M.M. (2015).BUCKMAN's rules of covariation. In: KLUG C., KoRn D., De BAETS K., KRUTA I. \& MAPES R.H. (eds.), Ammonoid Paleobiology: From macroevolution to paleogeography.- Topics in Geobiology, Gainesville, vol. 44, p. 67-94.

NAIDIN D.P. \& SHIMANSKI V.N. (1959).- Class Cephalopoda. Subclass Ectocochlia. In: Moskvin M.M. (ed.), Atlas of the Upper Cretaceous Fauna of North Caucasus and Crimea.- Moscow, p. $166-220$.

Niebuhr B., Hiss M., Kaplan U., Tröger K.-A., Voigt S., Voigt T., Wiese F. \& Wilmsen M. (2007).- Lithostratigraphie der norddeutschen Oberkreide.- Schriftenreihe der Deutschen Gesellschaft für Geowissenschaften, Hannover, no. 55,136 p.

ORBIGNY A. d' (1840-1842).- Paléontologie française, description zoologique et géologique de tous les animaux mollusques et rayonnés fossiles de France. Terrains Crétacés, Vol. I. Céphalopodes.- Masson, Paris, $662 \mathrm{p}$.

ORBIGNY A. d' (1850).- Prodrome de Paléontologie stratigraphique universelle des animaux mollusques et rayonnés, 2.- Masson, Paris, $427 \mathrm{p}$.

PORTHAULt B. (1974, unpublished).- Le Crétacé supérieur de la fosse vocontienne et des régions limitrophes (France sud-est). Micropaléontologie, stratigraphie, paléogéographie.Thesis, Claude Bernard University, Lyon, 342 p.

RafFi M.E. \& Olivero E.B. (2016).- The ammonite genus Gaudryceras from the Santonian-Campanian of Antarctica: systematics and biostratigraphy.- Ameghiniana, Buenos Aires, vol. 53, no. 3, p. 375-396.

REDTENBACHER A. (1873).- Die Cephalopodenfauna der Gosauschichten in den nördlichen Kalkalpen. Abhandlungen der Kaiserlich-Königlichen geologischen Reichsanstalt, Wien, Band 5, p. 91-140.

ReusS A.E. (1845).- Die Versteinerungen der böhmischen Kreideformation.- Schweizerbart'sche Verlagsbuchhandlung und Druckerei, Stuttgart, $58 \mathrm{p}$.

Robaszynski F., AmÉdro F., Devalque Ch. \& MATRION B. (2014).- Le Turonien des massifs d'Uchaux et de la Cèze. Migration globale d'ammonites et conséquences sur la zonation internationale, rudistes et corrélations entre les massifs.- Académie royale des Sciences, des Lettres et des Beaux-Arts de Belgique, Brussels, $197 \mathrm{p}$.

RobaszYNSKI F., GONZÁLES Donoso J.M., LiNARES D., AMÉdRo F., CARON M., Dupuis C., DHONDT A.V. \& GARTNER S. (2000).- Le Crétacé supérieur de la région de Kalaat Senan, Tunisie centrale. Lithobiostratigraphie intégrée: Zones d'ammonites, de foraminifères planctoniques et de nannofossiles du Turonien Supérieur au
Maastrichtien.- Bulletin des Centres de Recherches Exploration-Production elf-Aquitaine, Pau, vol. 22, p. 359-490.

ROEMER F.A. (1841).- Die Versteinerungen des norddeutschen Kreidegebirges, 2.- Hahn'schen Hofbuchhandlung, Hannover, $145 \mathrm{p}$.

RomAn F. (1912).- Coup d'oeil sur les zones de céphalopodes du Turonien du Vaucluse et du Gard. Comptes Rendus de l'Association française pour l'Avancement des Sciences, Mémoire hors Volume, Congrès de Nîmes, Paris, $15 \mathrm{p}$.

Roman F. \& Mazeran P. (1913).- Monographie paléontologique de la Faune du Turonien du bassin d'Uchaux et de ses dépendances.- Archives du Muséum d'Histoire naturelle de Lyon, t. 12, $137 \mathrm{p}$.

Santamaria Zabala R. (1992).- Los Ammonoideos del Cenomaniense superior al Santoniense de la plataforma nord-castellana y la cuenca navarro-cántabra. Parte I. Bioestratigrafiá y sistemática: Phylloceratina, Ammonitina (Desmocerataceae y Hoplitaceae) y Ancyloceratina.Treballs del Museu de Geologia de Barcelona, vol. 2, p. 171-268.

SCHLÜTER C. (1871-1876).- Cephalopoden der oberen deutschen Kreide.- Verlag von Gustav Fischer, Cassel, $264 \mathrm{p}$.

SHARPE D. (1853-1857).- Description of the fossil remains of Mollusca found in the Chalk of England. I, Cephalopoda.- Palaeontographical Society Monographs, London, $68 \mathrm{p}$.

SoRnAY J. (1939).- Sur la présence du Turonien dans l'Ouest du bassin de Dieulefit.- Comptes Rendus hebdomadaires des Séances de l'Académie des Sciences, Paris, t. 209, p. 116-117.

SORNAY J. (1946).- Le crétacé supérieur dans l'Ouest du département de la Drôme et dans les régions voisines.- Travaux du Laboratoire de Géologie de la Faculté des Sciences de I'Université de Grenoble, t. 25, p. 9-31.

SORNAY J. (1950).- Étude stratigraphique sur le Crétacé supérieur de la vallée du Rhône entre Valence et Avignon et des régions voisines.Thesis, Travaux du Laboratoire de Géologie de la Faculté des Sciences de I'Université de Grenoble, t. 27, p. 35-278.

SORNAY J. (1964).- Sur un Lewesiceras nouveau du Turonien d'Uchaux (Vaucluse).- Annales de Paléontologie, Paris, t. 50, p. 183-187.

SPATH L.F. (1926).- On New Ammonites from the English Chalk.- Geological Magazine, London, vol. 63, p. 77-83.

SPATH L.F. (1939).- Problems of ammonite nomenclature. 6. The genus Pachydiscus ZitTEL.Geological Magazine, London, vol. 76, p. 293296.

SUMmeSBerger H. (1992).- Ammoniten aus dem Turon (Oberkreide) der Nördlichen Kalkalpen (Österreich).- Annalen des Naturhistorischen Museums in Wien, A, Band 94, p. 103-133. 
Summesberger H. \& Kennedy W.J. (1996).- Turonian ammonites from the Gosau Group (Upper Cretaceous; Northern Calcareous Alps; Austria) with a revision of Barroisiceras haberfellneri (HAUER, 1866).- Beiträge zur Paläontologie, Wien, no. 21, p. 105-177.

SzÁsz L. \& ION J. (1988).- Crétacé supérieur du Bassin de Babadag (Roumanie). Biostratigraphie intégrée (Ammonites, Inocérames, Foraminifères planctoniques).- Memorii, Institutul de Geologie si Geofizica, Bucharest, vol. 33, p. 91-149.

THOMEL G. (1969).- Sur quelques ammonites turoniennes et sénoniennes nouvelles ou peu connues.- Annales de Paléontologie (Invertébrés), Paris, t. 55, fasc. 1, p. 111-124.

Thomel G. (1992).- Ammonites du Cénomanien et du Turonien du Sud-Est de la France. Tome 2, Considérations sur les faunes d'ammonites cénomaniennes et turoniennes des chaînes subalpines méridionales (Alpes de Haute-Provence, Alpes-Maritimes, Var).- Serre Ed., Nice, $383 \mathrm{p}$.

THomel G. (1993).- Biostratigraphie et faunes d'ammonites du Cénomanien et du Turonien inférieur dans le sud-est de la France.- Cretaceous Research, vol. 14, p. 455-475.

TRÖGER K.-A. (1968).- Bemerkungen zu Hyphantoceras reussianum (D'ORBIGNY).- Freiberger Forschungshefte, Band C234, p. 45-49.

TRÖGER K.-A. \& VoIGT T. (1995).- Event- und Sequenzstratigraphie in der sächsischen Kreide.Berliner Geowissenschaftliche Abhandlungen, Band E16, p. 255-267.

Tzankov V. (1982).- Les fossiles de Bulgarie. Crétacé supérieur. Cephalopoda (Nautiloidea, Ammonoidea) et Echinodermata (Echinoidea).Éditions de l'Académie Bulgare des Sciences, Sofia, $126 \mathrm{p}$.

WALASZCZYK I. (1988).- Inoceramid stratigraphy of the Turonian and Coniacian strata in the environs of Opole (Southern Poland).- Acta Geologica Polonica, Warsaw, vol. 38, no. 1-4, p. 51-61.

Walaszczyk I., WoOd C.J., Lees J.A., PeRYt D., Voigt S. \& Wiese F. (2010).- The SalzgitterSalder Quarry (Lower Saxony, Germany) and Słupia Nadbrzeżna river cliff section (central Poland): A proposed candidate composite Global Boundary Stratotype Section and Point for the Coniacian Stage (Upper Cretaceous).- Acta Geologica Polonica, Warsaw, vol. 60, no. 4, p. 445-477.

WANDERER K. (1909).- Die wichtigsten Tierversteinerungen aus der Kreide des Königreiches Sachsen.- Verlag von Gustav Fischer, Jena, 81 p.

Westermann G.E.G. (1966).- Covariation and taxonomy of the Jurassic ammonite Sonninia adicra (WAAGEN).- Neues Jahrbuch für Geologie und Paläontologie, Abhandlungen, Stuttgart,
Band 124, Heft 3, p. 289-312.

WiedmanN J. (1962).- Ammoniten aus der Vascogotischen Kreide (Nordspanien). I, Phylloceratina, Lytoceratina.- Palaeontographica Abteilung $A$, Stuttgart, Band 118, Lfg. 4-6, p. 119237.

Wiese F. (2000a).- On some Late Turonian and Early Coniacian (Upper Cretaceous) heteromorph ammonites from Germany.- Acta Geologica Polonica, Warsaw, vol. 50, no. 4, p. 407-419.

WIESE F. (2000b).- Coniacian (Upper Cretaceous) ammonites from the North Cantabrian Basin (Cantabria, northern Spain).- Acta Geologica Polonica, Warsaw, vol. 50, no. 1, p. 125-141.

Wiese F. (2009).- Additional Prionocyclus germari (Reuss, 1845) (Cretaceous Ammonoidea, Upper Turonian) from NW Germany.- Berliner paläobiologische Abhandlungen, Band 10, p. 361-371.

Wiese F. \& Kaplan U. (2004).- Der Mittel-/OberTuron Grenzbereich im Raum Lengerich.- Geologie und Paläontologie in Westfalen, Münster, Heft 62, p. 37-70.

WIESE F. \& KRÖGER B. (1998).- Evidence for a shallowing event in the Upper Turonian (Cretaceous) Mytiloides scupini Zone of northern Germany.- Acta Geologica Polonica, Warsaw, vol. 48 , no. 3, p. 265-284.

WilmSEN M. \& NAGM E. (2013).- Upper Cenomanian-Lower Turonian ammonoids from the Saxonian Cretaceous (lower Elbtal Group, Saxony, Germany).- Bulletin of Geosciences, Prague, vol. 88, issue 3, p. 647-674.

WiLMSEN M. \& NAGM E. (2014).- Ammoniten. In: Niebuhr B. \& Wilmsen M. (eds.), KreideFossilien in Sachsen, Teil 1.- Geologica Saxonica, Dresden, Band 60, Heft 1, p. 201240.

WRIGHT C.W. (1979).- The ammonites of the English Chalk Rock (Upper Turonian).- Bulletin of the British Museum (Natural History) Geology, London, vol. 31, no. 4, p. 281-332.

WRIGHT C.W. (1996) with CALLOMON J.H. \& HoWARTH M.K.- Cretaceous Ammonoidea. In: KAESLER R.L. (ed.), Treatise on invertebrate paleontology, Part L, Mollusca 4, Cretaceous Ammonoidea.- University of Kansas Press and Geological Society of America, Lawrence, 362 p.

Wright C.W. \& Kennedy W.J. (1981).- The Ammonoidea of the Plenus Marls and the Middle Chalk.- Palaeontographical Society Monographs, London, $148 \mathrm{p}$.

WRIGHT C.W. \& KenNEDY W.J. (2002).- Ammonites. In: SмITH A.B. \& BATTEN D.J. (eds.), Fossils of the Chalk, Second edition, revised and enlarged.- The Palaeontological Association, London, p. 176-218.

WRIGHT C.W. \& WRIGHT E.V. (1951).- A survey of the fossil Cephalopoda of the Chalk of Great 
Britain.- Paleontographical Society, London, $40 \mathrm{p}$.

YeHARA S. (1924).- On the Izumi sandstone group in the Onogawa Basin, Province of Bungo, and the same group in the Uwajima, Province of Iyo.- Japanese Journal of Geology and Geography, Tokyo, vol. 3, p. 27-39.

\section{Plates}

\section{Plate 1:}

Fig. 1a-b: Gaudryceras mite (HAUER, 1866). Specimen no. Rch13, late Turonian, Prionocyclus germari Zone, Rochefort-en-Valdaine (Drôme, France).

Fig. 2: cf. Mesopuzosia Matsumoto, 1954. Specimen no. Rch38, late Turonian, Prionocyclus germari Zone, Rocheforten-Valdaine (Drôme, France).

Asterisks indicate the beginning of the body chamber. 

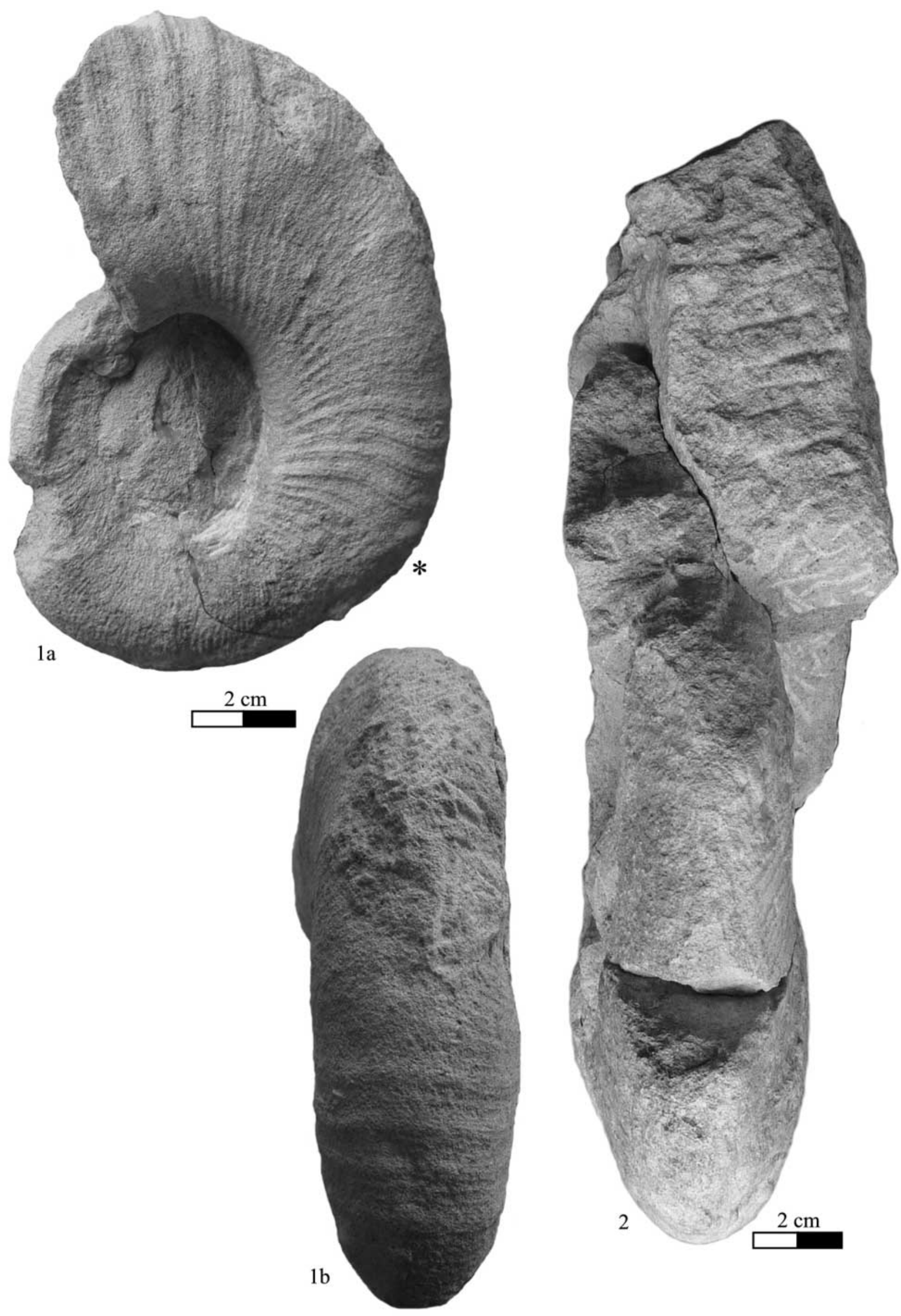
Plate 2: Fig. 1: cf. Mesopuzosia Matsumoto, 1954. Specimen no. Rch38, late Turonian, Prionocyclus germari Zone, Rochefort-en-Valdaine (Drôme, France). 


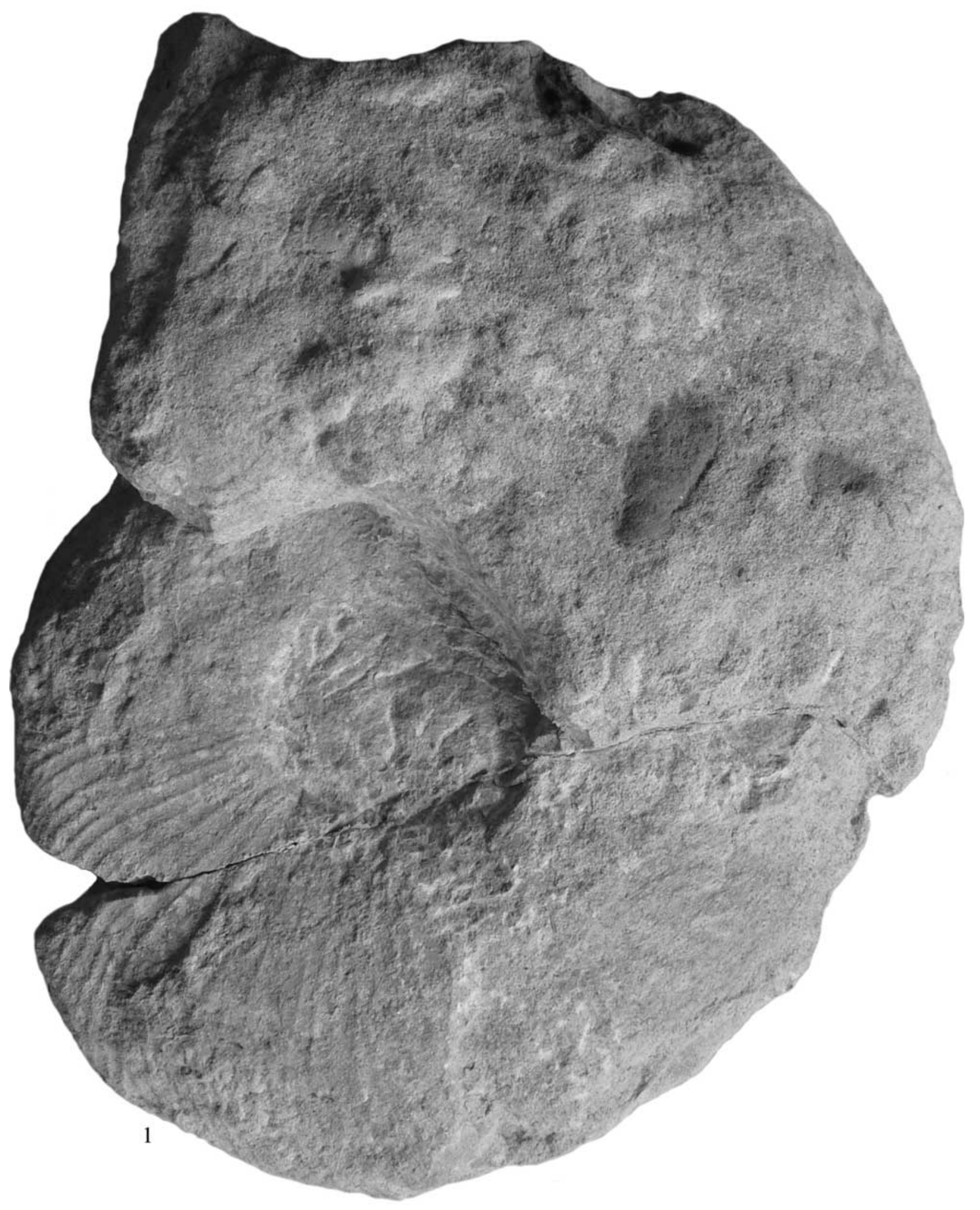




\section{Plate 3:}

Fig. 1: cf. Mesopuzosia Matsumoto, 1954. Specimen no. Rch38, late Turonian, Prionocyclus germari Zone, Rocheforten-Valdaine (Drôme, France).

Fig. 2a-c: Lewesiceras mantelli C.W. WRIGHT \& E.V. WRIGHT, 1951. Specimen no. Rch21, late Turonian, Prionocyclus germari Zone, Rochefort-en-Valdaine (Drôme, France).

Fig. 3a-b: Lewesiceras mantelli C.W. WRIGHT \& E.V. WRIGHT, 1951. Specimen no. Rch20, late Turonian, Prionocyclus germari Zone, Rochefort-en-Valdaine (Drôme, France). 

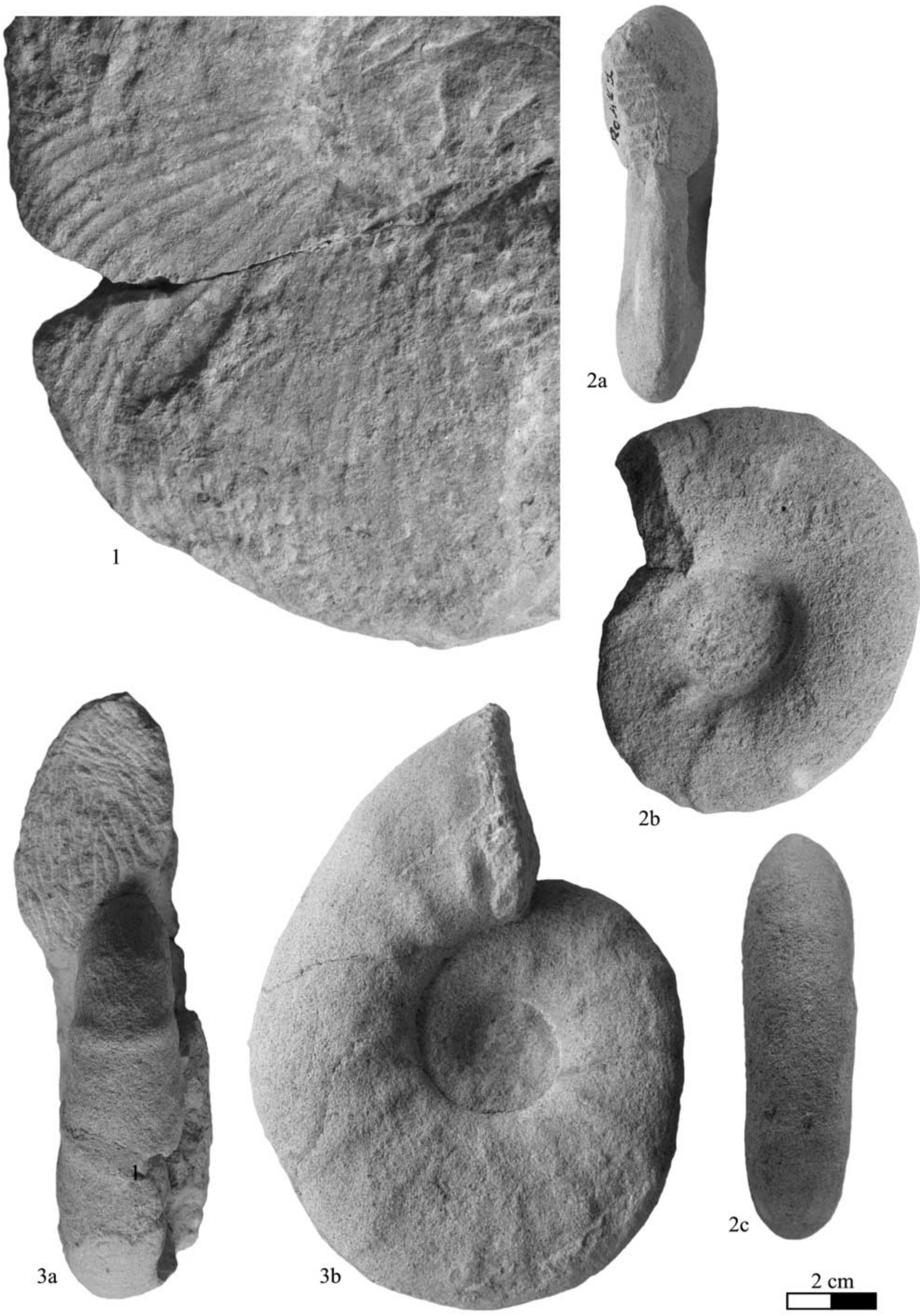
Plate 4: Fig. 1: Lewesiceras mantelli C.W. WRIGHT \& E.V. WRIGHT, 1951. Specimen no. 955, late Turonian, Prionocyclus germari Zone, Rochefort-en-Valdaine (Drôme, France). CHATELIER coll. Asterisks indicate the beginning of the body chamber. 
2

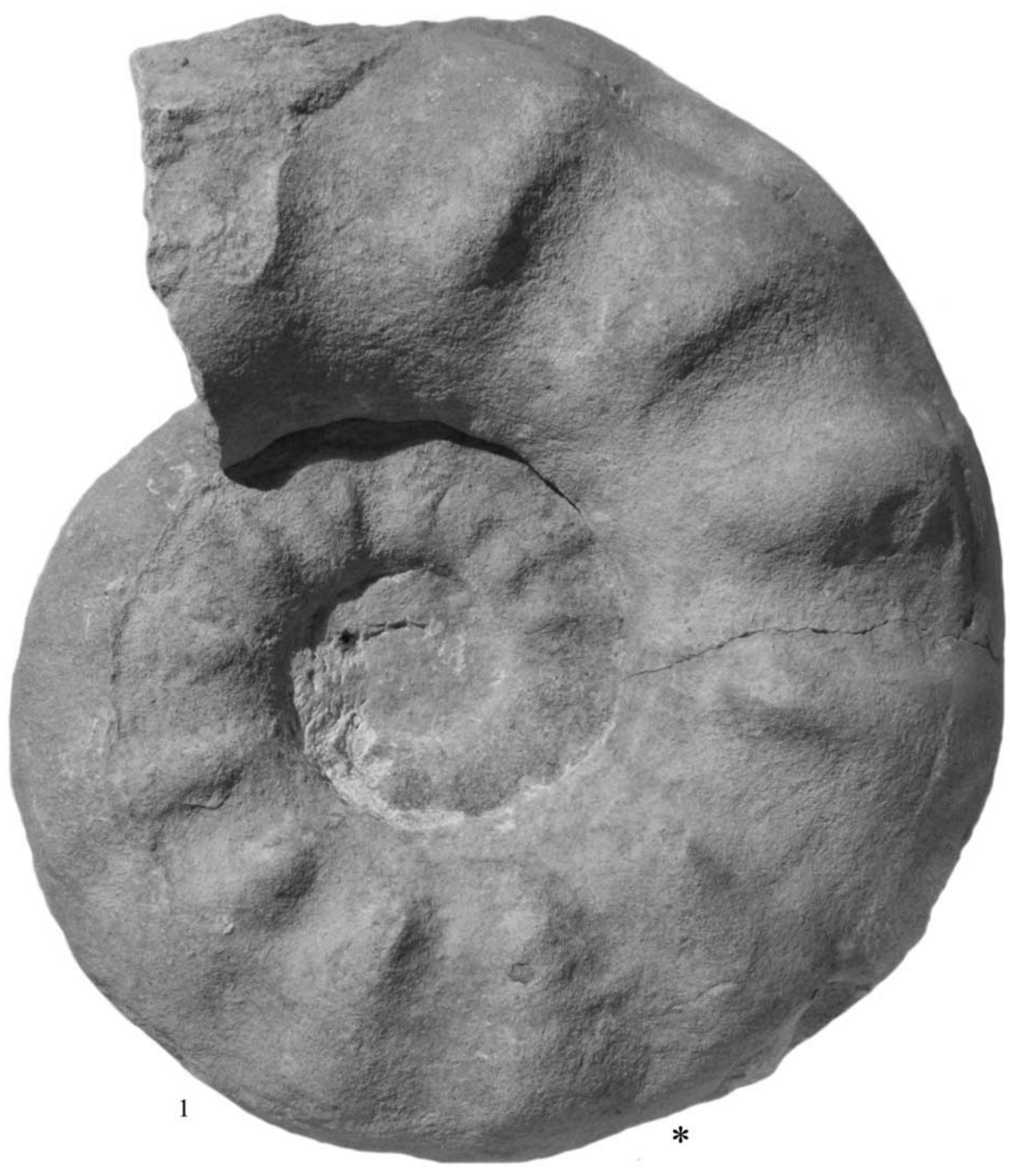

$2 \mathrm{~cm}$ 


\section{Plate 5:}

Fig. 1: Lewesiceras mantelli C.W. WRIGHT \& E.V. WRIGHT, 1951. Specimen no. 955, late Turonian, Prionocyclus germari Zone, Rochefort-en-Valdaine (Drôme, France). CHATELIER coll.

Fig. 2a-b: Lewesiceras mantelli C.W. WRIGHT \& E.V. WRIGHT, 1951. Specimen no. 960, late Turonian, Prionocyclus germari Zone, Rochefort-en-Valdaine (Drôme, France). CHATELIER coll.

Fig. 3a-b: Prionocyclus germari (Reuss, 1845). Specimen no. Rch12, late Turonian, Prionocyclus germari Zone, Rochefort-en-Valdaine (Drôme, France). 


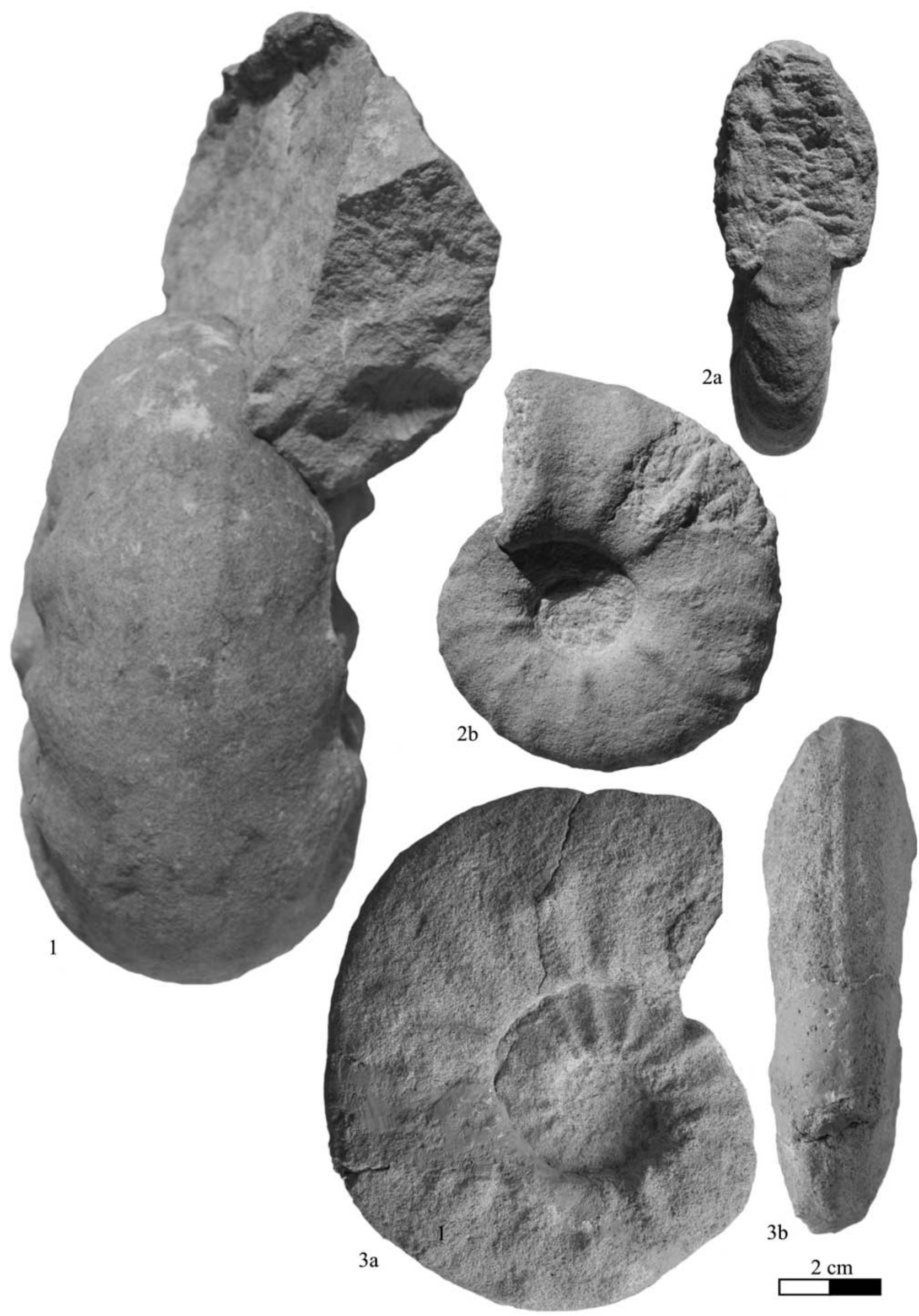




\section{Plate 6:}

Fig. 1a-c: Vocontiiceras vocontiense Diebold et al., 2018. Paratype no. Rch01, late Turonian, Prionocyclus germari Zone, Rochefort-en-Valdaine (Drôme, France).

Fig. 2a-b: Vocontiiceras vocontiense Diebold et al., 2018. Paratype no. Rch08, late Turonian, Prionocyclus germari Zone, Rochefort-en-Valdaine (Drôme, France).

Fig. 3a-b: Vocontiiceras vocontiense Diebold et al., 2018. Specimen no. Rch04, late Turonian, Prionocyclus germari Zone, Rochefort-en-Valdaine (Drôme, France).

Fig. 4a-c: Vocontiiceras vocontiense Diebold et al., 2018. Specimen no. Rch11, late Turonian, Prionocyclus germari Zone, Rochefort-en-Valdaine (Drôme, France).

Fig. 5a-b: Vocontiiceras vocontiense Diebold et al., 2018. Specimen no. Rch42, late Turonian, Prionocyclus germari Zone, Rochefort-en-Valdaine (Drôme, France).

Asterisks indicate the beginning of the body chamber. 

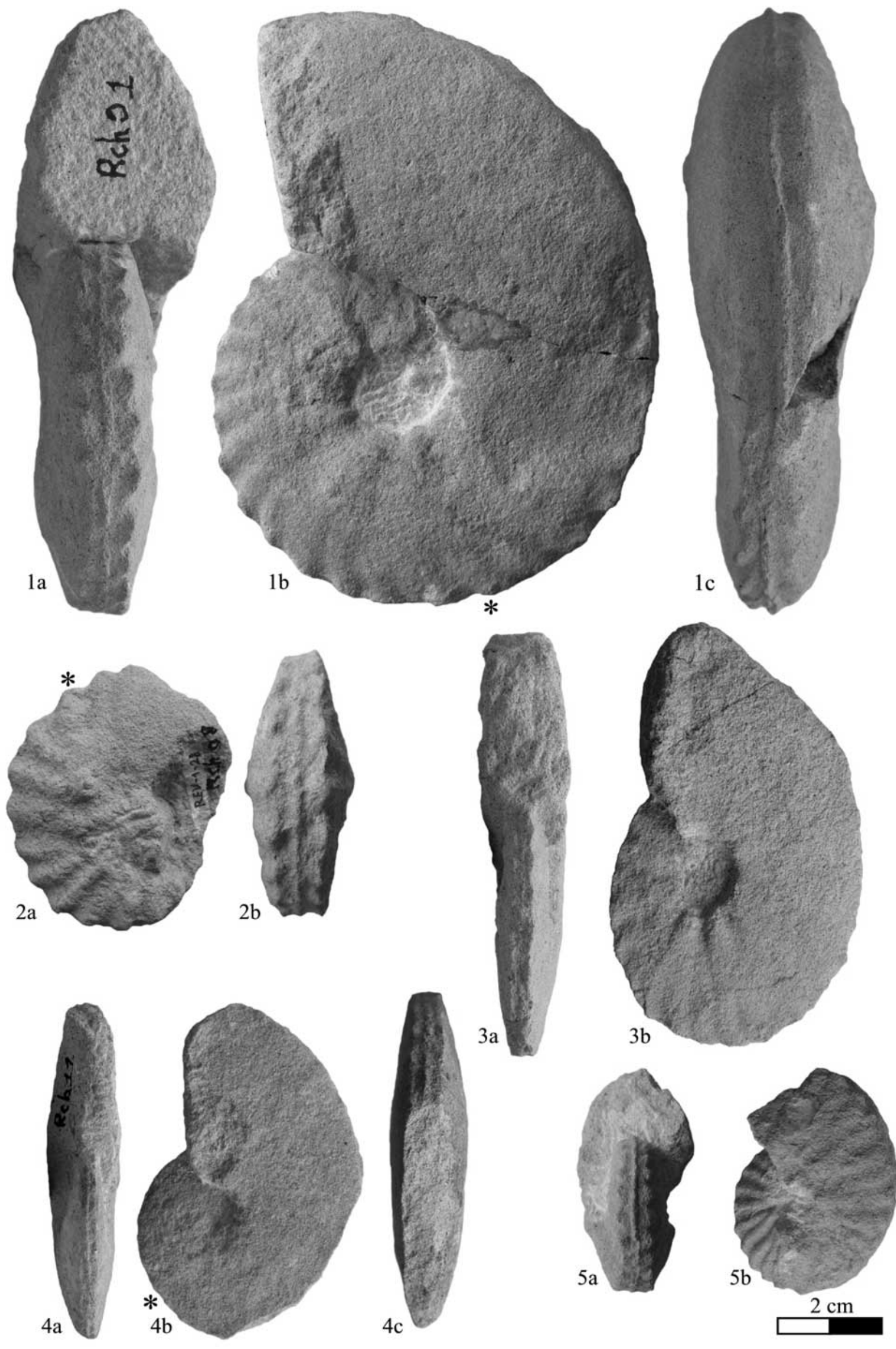


\section{Plate 7:}

Fig. 1a-c: Vocontiiceras vocontiense DieBold et al., 2018. Paratype no. Rch02, late Turonian, Prionocyclus germari Zone, Rochefort-en-Valdaine (Drôme, France).

Fig. 2a-c: Vocontiiceras vocontiense Diebold et al., 2018. Specimen no. Rch06, late Turonian, Prionocyclus germari Zone, Rochefort-en-Valdaine (Drôme, France).

Fig. 3a-b: Vocontiiceras vocontiense DieBold et al., 2018. Specimen no. Rch05, late Turonian, Prionocyclus germari Zone, Rochefort-en-Valdaine (Drôme, France).

Fig. 4a-b: Vocontiiceras vocontiense Diebold et al., 2018. Specimen no. Rch47, late Turonian, Prionocyclus germari Zone, Rochefort-en-Valdaine (Drôme, France).

Asterisks indicate the beginning of the body chamber. 


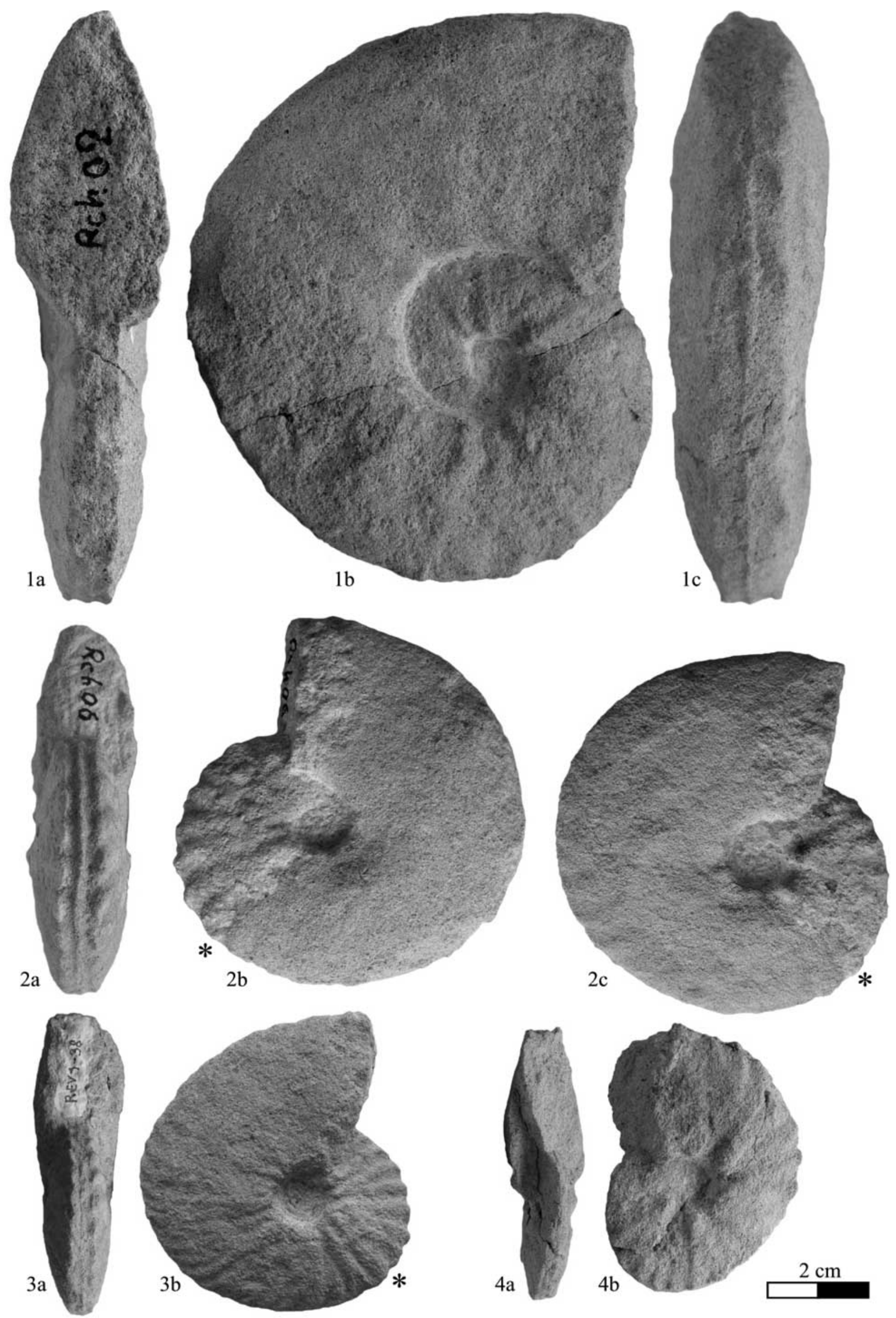




\section{Plate 8:}

Fig. 1a-b: Vocontiiceras vocontiense Diebold et al., 2018. Specimen no. Rch60, late Turonian, Prionocyclus germari Zone, Rochefort-en-Valdaine (Drôme, France).

Fig. 2a-b: Vocontiiceras vocontiense DieBold et al., 2018. Paratype no. Rch10, late Turonian, Prionocyclus germari Zone, Rochefort-en-Valdaine (Drôme, France).

Fig. 3a-b: Vocontiiceras vocontiense Diebold et al., 2018. Paratype no. Rch07, late Turonian, Prionocyclus germari Zone, Rochefort-en-Valdaine (Drôme, France).

Fig. 4a-b: Vocontiiceras vocontiense Diebold et al., 2018. Specimen no. Rch03, late Turonian, Prionocyclus germari Zone, Rochefort-en-Valdaine (Drôme, France).

Fig. 5a-b: Vocontiiceras vocontiense Diebold et al., 2018. Specimen no. Rch61, late Turonian, Prionocyclus germari Zone, Rochefort-en-Valdaine (Drôme, France).

Asterisks indicate the beginning of the body chamber. 

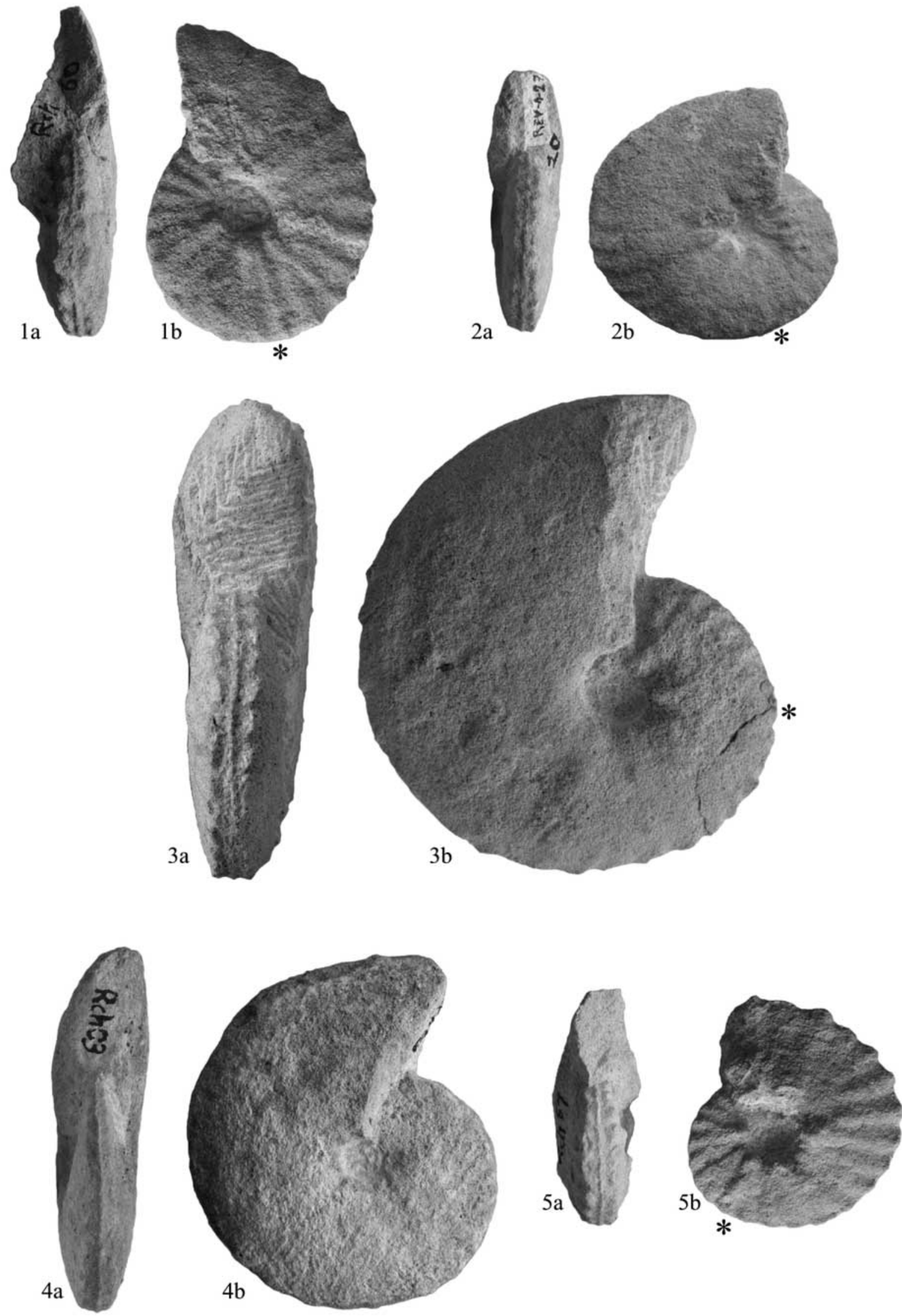

$2 \mathrm{~cm}$ 


\section{Plate 9:}

Fig. 1a-c: Hyphantoceras (Hyphantoceras) flexuosum (SCHLÜTER, 1872). Specimen no. Rch14, late Turonian, Prionocyclus germari Zone, Rochefort-en-Valdaine (Drôme, France).

Fig. 2a-b: Hyphantoceras (Hyphantoceras) ernsti WIESE, 2000. Specimen no. Rch19, late Turonian, Prionocyclus germari Zone, Rochefort-en-Valdaine (Drôme, France).

Fig. 3a-b: Hyphantoceras (Hyphantoceras) ernsti WIESE, 2000. Specimen no. Rch51, late Turonian, Prionocyclus germari Zone, Rochefort-en-Valdaine (Drôme, France).

Fig. 4a-b: Hyphantoceras (Hyphantoceras) ernsti WIESE, 2000. Specimen no. Rch17, late Turonian, Prionocyclus germari Zone, Rochefort-en-Valdaine (Drôme, France).

Fig. 5a-b: Hyphantoceras (Hyphantoceras) ernsti WIESE, 2000. Specimen no. Rch18, late Turonian, Prionocyclus germari Zone, Rochefort-en-Valdaine (Drôme, France).

Fig. 6: Hyphantoceras (Hyphantoceras) ernsti WIESE, 2000. Specimen no. Rch16, late Turonian, Prionocyclus germari Zone, Rochefort-en-Valdaine (Drôme, France).

Fig. 7: Sciponoceras bohemicum bohemicum (FRITSCH, 1872). Specimen no. Rch44, late Turonian, Prionocyclus germari Zone, Rochefort-en-Valdaine (Drôme, France).

Fig. 8: Sciponoceras bohemicum bohemicum (FRITSCH, 1872). Specimen no. Rch45, late Turonian, Prionocyclus germari Zone, Rochefort-en-Valdaine (Drôme, France).

Fig. 9: Scaphites geinitzii ORBigny, 1850 [M]. Specimen no. Rch63, late Turonian, Prionocyclus germari Zone, Rochefort-en-Valdaine (Drôme, France).

Fig. 10a-b: Scaphites geinitzii ORBIGNY, 1850 [M]. Specimen no. Rch59, late Turonian, Prionocyclus germari Zone, Rochefort-en-Valdaine (Drôme, France).

Fig. 11: Scaphites geinitzii Orbigny, 1850 [M]. Specimen no. Rch53, late Turonian, Prionocyclus germari Zone, Rochefort-en-Valdaine (Drôme, France).

Fig. 12a-c: Scaphites geinitzii ORBIGnY, 1850 [M]. Specimen no. Rch25, late Turonian, Prionocyclus germari Zone, Rochefort-en-Valdaine (Drôme, France).

Fig. 13a-b: Scaphites geinitzii ORBIGNY, 1850 [M]. Specimen no. Rch27, late Turonian, Prionocyclus germari Zone, Rochefort-en-Valdaine (Drôme, France).

Fig. 14: Scaphites geinitzii ORBIGnY, 1850 [M]. Specimen no. Rch26, late Turonian, Prionocyclus germari Zone, Rochefort-en-Valdaine (Drôme, France).

Fig. 15: Scaphites geinitzii ORBIGNY, 1850 [M]. Specimen no. Rch50, late Turonian, Prionocyclus germari Zone, Rochefort-en-Valdaine (Drôme, France).

Fig. 16: Scaphites geinitzii ORBIGNY, 1850 [M]. Specimen no. Rch32, late Turonian, Prionocyclus germari Zone, Rochefort-en-Valdaine (Drôme, France).

Fig. 17: Scaphites geinitzii ORBIGNY, 1850 [M]. Specimen no. Rch31, late Turonian, Prionocyclus germari Zone, Rochefort-en-Valdaine (Drôme, France).

Fig. 18: Scaphites geinitzii ORbignY, 1850 [M]. Specimen no. Rch67, late Turonian, Prionocyclus germari Zone, Rochefort-en-Valdaine (Drôme, France).

Fig. 19: Scaphites geinitzii ORBIGNy, 1850 [m] ?. Specimen no. Rch57, late Turonian, Prionocyclus germari Zone, Rochefort-en-Valdaine (Drôme, France).

Fig. 20: Scaphites geinitzii ORBIGNy, 1850 [m] ?. Specimen no. Rch35, late Turonian, Prionocyclus germari Zone, Rochefort-en-Valdaine (Drôme, France).

Asterisks indicate the beginning of the body chamber. 

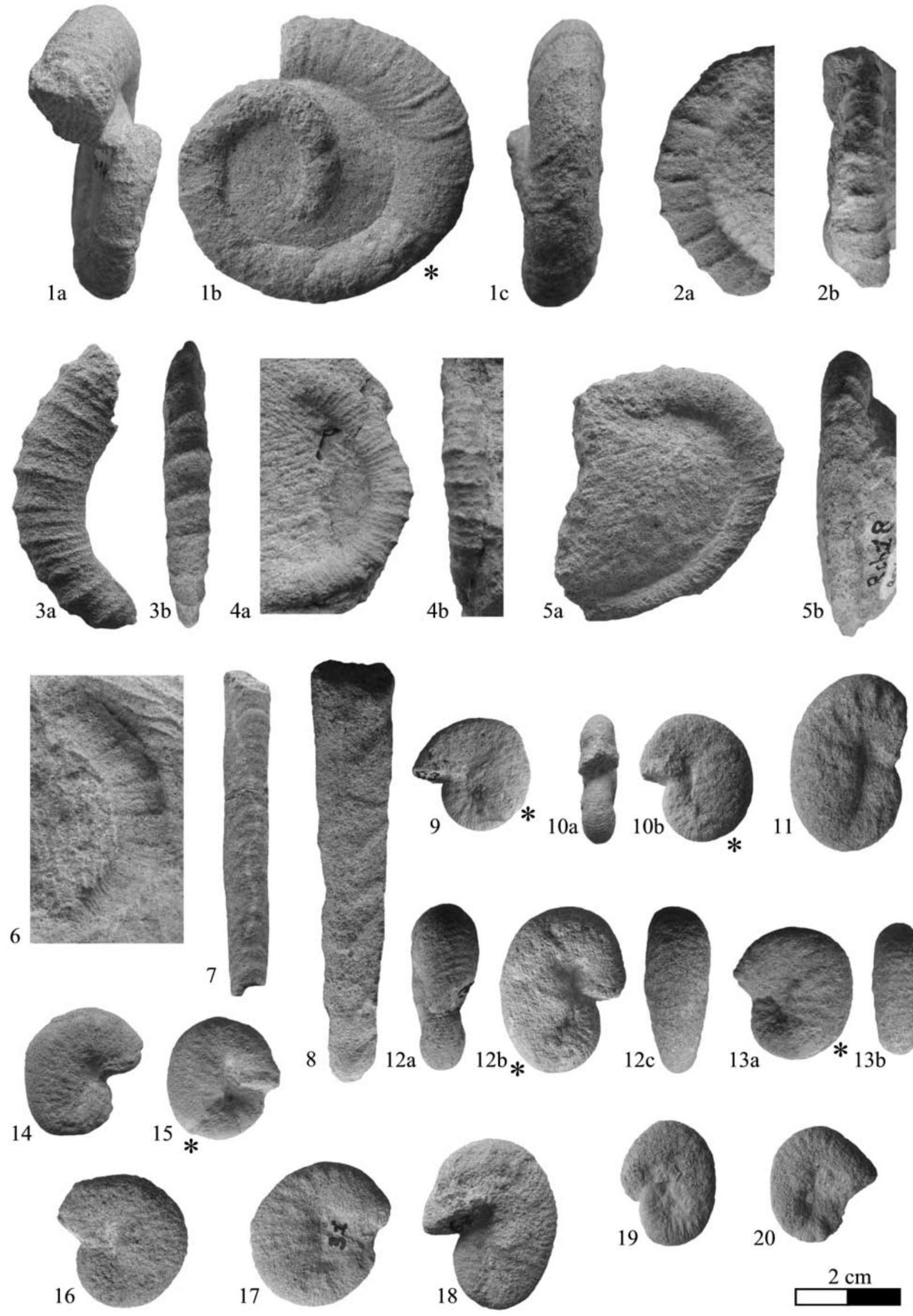